\title{
IMPLICATION OF THE CARAÍBA DEPOSIT'S STRUCTURAL CONTROLS ON THE EMPLACEMENT OF THE CU-BEARING HYPERSTHENITES OF THE CURAÇÁ VALLEY, BAHIA-BRAZIL
}

\author{
LUIZ JOSÉ HOMEM D'EL-REY SILVA*, JOSÉ GENÁRIO DE OLIVEIRA** \& \\ EDMUND GABOR GAAL $* * * *$
}

\begin{abstract}
RESUMO IMPLICATES DOS CONTROLES ESTRUTURAIS DO DEPÓSITO CARAÍBANA COLOCAÇÃO DOS CORPOS CUPRIFEROS DO VALE DO CURAÇA, BAHIA - BRASIL O depósito cuprífero Caraíba é o maior dentre diversos corpos de rochas máficas-ultramáficas encontradas no Vale do Curaçá (norte do Estado da Bahia) na parte norte do Cráton do São Francisco. O depósito, que vem sendo explorado desde 1978, consiste de hiperstenitos e noritos mineralisados a calcopirita e bornita disseminadas e/ou em agregados disformes. O Vale do Curaçá é um terreno de alto grau metamórfico compreendendo supracrustais, gnaisses do seu provável embasamento e as rochas máficas/ultramáficas colocadas como sills, sendo todas intrudidas por ortognaisses tonalíticos/granodioríticos e granites $\left(\mathrm{G}_{1}-\mathrm{G}_{3}\right)$ Cedo- a tardi-tectônicos a eventos deformacionais altamente dụcteis ocorridos entre 2.25 e $2.05 \mathrm{Ga}$ (idade U-Pb de zircões). Eventos finals e localisados ocorreram sob fácies xisto verde até cerca de 1,9 Ga atrás (isócrona Sm-Nd de rocha total em hiperstenitos). A excecão de $\mathrm{G}_{2}$ e $\mathrm{G}_{3}$ todas as rochas já mencionadas apresentam um bandamento metamórfico penetrative (Si) no fácies anfibolito afetado por duas fases de dobramentos respectivamente associados a metamorfismo de fácies granulito e anfibolito. Devido à interferência desses dobramentos mais jovens o depósito Carába adquiriu a forma de um cogumelo, com cerca de $5 \mathrm{~km}$ de comprimento $\mathrm{N}-\mathrm{S}$ e $800 \mathrm{~m}$ de largura E-W, e encontra-se alojado em sinforma com piano axial fortemente inclinado para oeste e com caimento duplo de eixo para $\mathrm{N}$ ou S, fazendo parte do flanco oeste da estrutura maior - a antiforma Caraíba. A complexa geometria do depósito, aliada ao intense desmembramento rúptil-dúctil que 0 afetou durante a evolução estrutural da área, tem dificultado o planejamento e as operações de lavra. Uma vez que o corpo mineral atuou como barreira relativamente resistente à deformação intensa e rica em mobilisados da terceira fase, as estruturas da segunda fase puderam ser melhor preservadas nas cercanias de Caraíba, e este fator contribuiu sobremaneira para o entendimento da evolução tectônica do Vale do Curaçá. Os controles estruturais da mineralização cuprífera tem importantes implicações na gênese dos depósitos cupríferos da região, como discutido em detalhe.
\end{abstract}

Palavras-chaves: Evolução estrutural e tectônica, Mina Caraíba, terrenes granulíticos, Vale do Curaçá, Cráton do São Francisco Paleoproterozóico, idade U-Pb, minério de cobre

\begin{abstract}
The Caraíba deposit of Bahia, Brazil, is a Paleoproterozoic sill-like intrusion consisting of magnetite-bearing hypersthenites, melanorites and norites mainly mineralized with disseminated-type $\mathrm{Cu}$-ore (chalcopyrite and bornite) exploited since 1978. The intrusion is the largest of a set of 100's mafic-ultramafic bodies found within the Curaçá Valley terrane, a N-S trending strip of high grade rocks in the northern part of the São Francisco Craton. This terrane comprises supracrustais and gneisses of their probable basement, the mafic-ultramafic rocks emplaced as sills, all intruded by $\mathrm{G}_{1}-\mathrm{G}_{3}$ early- to late-tectonic tonalitic-granodioritic orthogneisses and granites related to highly ductile deformation events between 2.25 to $2.05 \mathrm{Ga}$ (U-Pb ages of zircons). Final and localized events under greenschist metamorphism lasted up to $1,9 \mathrm{Ga}$ (whole rock $\mathrm{Sm}-\mathrm{Nd}$ isochron on hypersthenites). A penetrative, layer-parallel amphibolite-facies metamorphic banding ( $\mathrm{Si}$ ) occurs in all mentioned rocks - apart from $\mathrm{G}_{2}$ and $\mathrm{G}_{3}$. and is affected by two younger folding events respectively under granulite and amphibolite facies. As a result of this evolution, the Caraíba $\mathrm{Cu}$-deposit is a N-S trending, tight-isoclinal and asymmetric $\mathrm{F}_{3}$ synform, with $1000 \mathrm{~m}$ of amplitude and axial plane dipping $70^{\circ}-75^{\circ}$ to the $\mathrm{W}$, and lies in the western limb of a normal, regional-scale $\mathrm{F}_{3}$ antiform plunging about $18^{\circ} \mathrm{S}$. However, because of the interference pattern of $F_{3}$ with $E-W$ trending $F_{2}$ folds, the deposit has a nearly $5 \mathrm{~km}$-long and $800 \mathrm{~m}$-wide mushroom shape. Brittle fracturing and boudinage disrupted the orebody throughout the structural evolution, so mining planning and underground exploitation are difficult in some parts of the mine. Because the Caraíba orebody was a relatively rigid barrier to the intense, ductile and melt assisted $\mathrm{D}_{3}$ event, the structural evolution of the Curaçá. Valley terrane is reconstructed with confidence. The evidence for $F_{2}$ folds in and around the ore-body is better preserved than elsewhere within the Curacá Valley high grade terrane, where most of the earlier structures were tightened and/or brought into parallelism with the $\mathrm{S}_{3}$ foliation. The structural controls of Caraiba also bear implications for the genesis of the orebody.
\end{abstract}

Key words: Structural and tectonic evolution, Caraíba Mine, high-grade terrane, Curaçá Valley, São Francisco Craton, Paleoproterozoic, U-Pb age, Copper ore

\section{INTRODUCTION - GEOLOGICAL SETTING The}

Caraíba Cu-deposit is situated in the Curaçá River Valley, in the north of Bahia, Brazil, and lies within a Paleoproterozoic, $\mathrm{N}-\mathrm{S}$ trending, granulite-amphibolite belt in the northern part of the São Francisco Craton. This high-grade terrane (Fig.l) is part of the Salvador-Curaçá belt (Sabate et al. 1990) which evolved as a consequence of the collision between the Serrinha and Mairi Archean continental blocks (Barbosa et al 1996, Barbosa 1996).

The Serrinha block occurs to the east of the Itiuba syenite (Fig.1): it consists of Archean gneisses and migmatites intruded by Cr-bearing mafic-ultramafic bodies, and also encloses Paleoproterozoic greenstone sequences and granites.
Farther to the east, the block is covered by Neoproterozoic (meta)sediments and by Mesozoic sediments of the Tucano basin. The Itiuba syenite is a N-S trending, long and narrow body intruded along a transcurrent zone that marks the eastern limit of the Curaçá Valley terrane. The intrusion was deformed and metamorphosed at amphibolite facies conditions, ca. 2.0 Ga ago ( Rb-Sr data in Figueiredo 1976, Brito Neves 1980, Conceição 1990). The Mairi block comprises the Archean gneisses and migmatites that occur to the west of the Curaçá Valley terrane (Fig.l). The eastern margin of this block encloses a major Cr-bearing mafic-ultramafic intrusion which is unconformably overlain by Paleoproterozoic metasediments and volcanics of the Jacobina Group, all intruded 


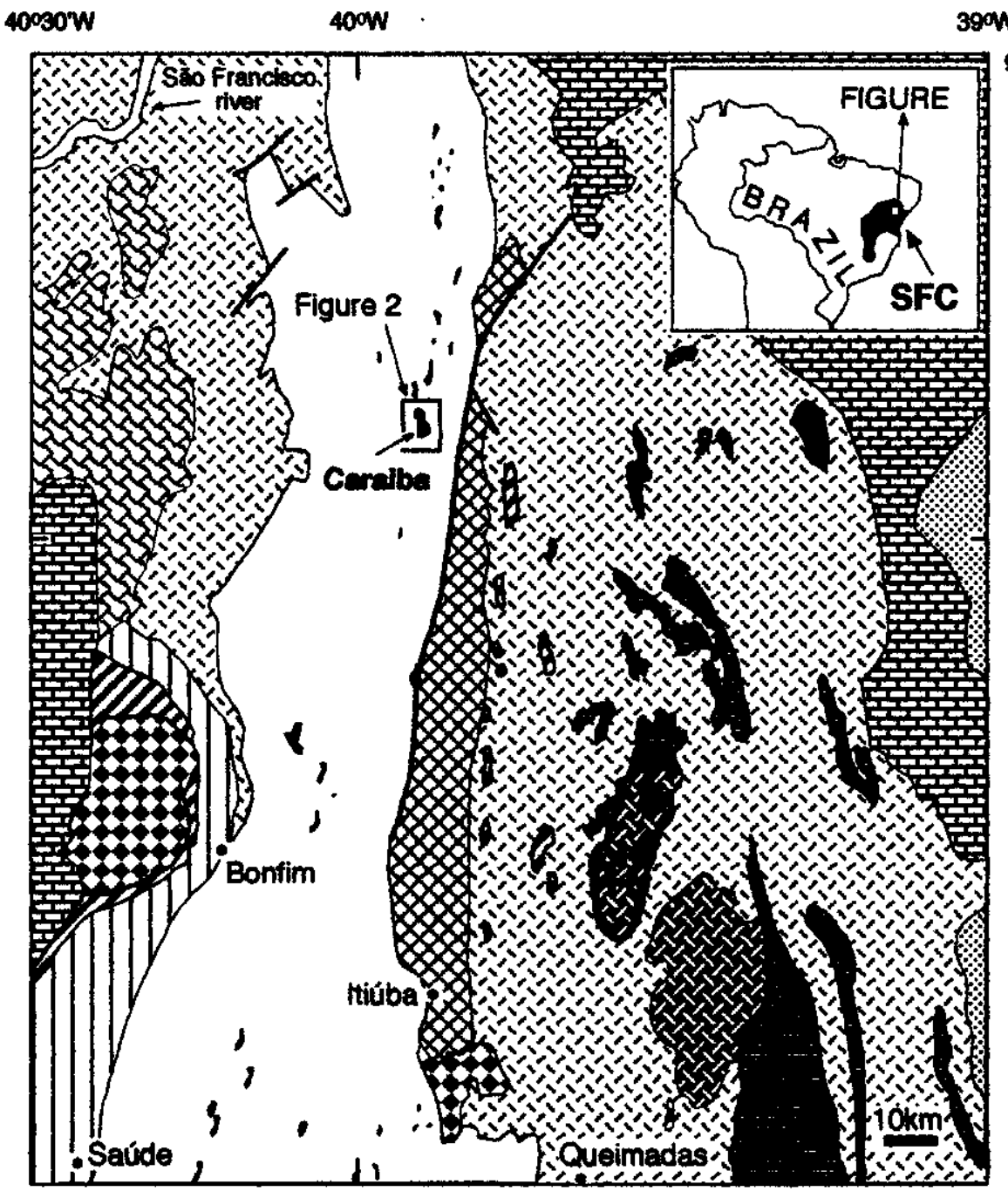

$390 \mathrm{~W}$

go15's

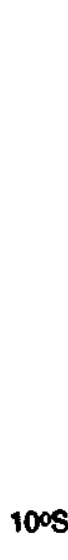

1005
NEOPROTEAOZOKC

BRASUUANO CYCLE (META)SEDIMENTARY COVER

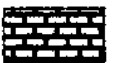

\section{PALEOPROTEROZZIC}

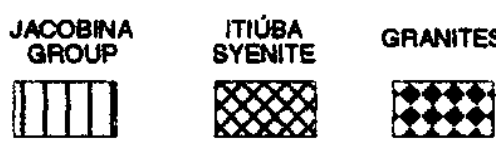

MKGH GPADE TEPRAIN INCLUDING Cl BEAPING M-LM BODIES
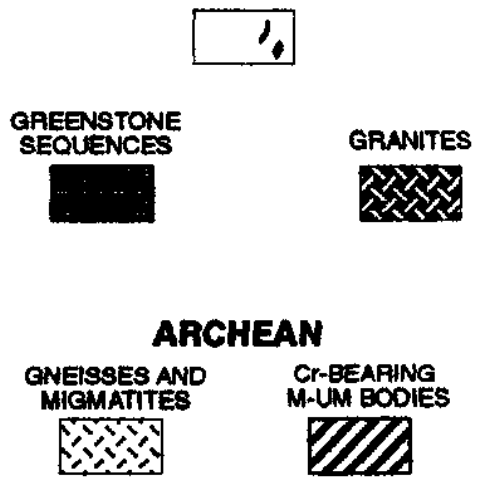

Figure 1 - Simplified geological map of the northern part of Bahia, Brazil, displaying the Caraiba hypersthenite-norite orebody, the high grade terrane including other Cu-bearing $M-U m$ bodies and the surrounding major lithotectonic units (Adapted from Inda \& Barbosa 1978 and based on Barbosa 1996, Barbosa et al. 1996, Silva 1996). See details in the text.

by a large (Meso)-Paleoproterozoic granite and unconformably overlain by (meta)sediments of the Neoproterozoic Brasiliano cycle and by Quaternary limestones (Inda and Barbosa 1978, Silva 1996).

The northern part of the Salvador-Curaçá belt encloses several mafic-ultramafic rocks, the vast majority of which is Cu-poor or simply barren (Lindenmayer 1981, D'el-Rey Silva 1984). The Cu-occurrence was known at Caraíba for more than a century, and is one among nearly three hundred bodies within the Curaçá River Valley, a $\mathrm{Cu}$-district that stretches northwards towards the São Francisco River (Fig. 1). The valuable bodies consist of magnetite-rich hypersthenites and/or norites. By the beginning of the 80 's, the known reserves in the district exceeded 150 million tons of ore, with 0.5 to $1.0 \%$ average $\mathrm{Cu}$ grade, _60\% being in Caraíba and the rest in other four smaller occurrences. Bodies consisting of gabbros, gabbronorites and anorthosites are generally $\mathrm{Cu}-$ poor or simply barren (Lindenmayer 1981). The extremely high $\mathrm{Cu}: \mathrm{Ni}$ ratio displayed by the mafic-ultramafic rocks (up to $1: 2,500$, according to Mayer \& Barnes 1996), the lithological and geochemical characteristics of the rocks hosting the mineralisation make these bodies fairly comparable with those in the Okiep Cu-District of Africa (Lindenmayer 1981, D'elRey Silva 1984).
Despite the fact that the $\mathrm{Cu}$-district has been studied for decades, most elucidative studies were carried out as MSc and $\mathrm{PhD}$ thesis (and their derivatives), published together and/or after the start-up of the Caraíba Mine operation in 1978-1979. Lindenmayer (1981), Mandetta (1982), Gaal (1982 a, b), Hasui et al. (1982), Jardim de Sá et al. (1982), and D'el-Rey Silva (1984 1985) established the basis for the understanding of the regional geology and for the structural evolution of the high-grade terrane.

These authors have shown that the Curaçá River Valley terrane is underlain by three main granulite-amphibolite facies lithostratigraphic units also mappable in the vicinities of the Caraíba orebody, all affected by a $\mathrm{D}_{1}-\mathrm{D}_{3}$ polyphase progressive deformation assisted by large volumes of sin-tectonic $\mathrm{G}_{1}-\mathrm{G}_{3}$ granitoid intrusions (Fig.2). A vast amount of geology and structural data collected regionally, and also in surface and underground sites of the Caraíba Mine and other small bodies, drove Lindenmayer (1981), Lindenmayer etal. (1984) and D'el-Rey Silva (1984) to interpret the Cu-bearing rocks as sill-like structures.

The Caraíba orebody attained a N-S trending, $\approx 5 \mathrm{~km}-$ long mushroom-shaped structure due to the interference patterns of E-W trending $\mathrm{F}_{2}$ folds and N-S trending $\mathrm{F}_{3}$ folds, both affecting a penetrative metamorphic banding found through- 
out the Mine and the high-grade terrane (D'el-Rey Silva 1984, 1985). The surface and underground mining operation up to 1994 brought to light a huge amount of additional data, confirming entirely the structure of the orebody and reinforcing the sill interpretation, placing constraints for the structural evolution of the Curaçá Valley terrane (D'el-Rey Silva et al 1988, 1994).

This paper summarises the geology and the structural evolution of the Caraíba Mine and the Curaçá Valley terrane, based on data obtained during successive stages of geological mapping and drilling for ore reserve evaluation in the Mine (1984 19881994 1996). We also present U-Pb age determinations for $\mathrm{G}_{2}$ and $\mathrm{G}_{3}$ granitoids in the surroundings of the Caraíba Mine. In addition, we also discuss the interpretation that the Caraíba mineralised complex is part of a swarm of sub-vertical, sheet-like post-or syn- $\mathrm{F}_{3}$ intrusions, as E.P. Oliveira and co-authors have been proposing in publications (1990-1995) based on petrology, chemistry, mineral analysis, geochronology and metamorphism studies carried out in the Caraíba Mine.

\section{THE CURACÁ HIGH GRADE TERRANE AROUND} THE CARAIIBA MINE Lithostratigraphy Figure 2 is a summary geological map based on a 1:10,000 scale mapping of the surroundings of the Caraíba Mine (D'el-Rey Silva 1984). The oldest lithostratigraphic unit in the area is a typical supracrustal sequence consisting mostly of quartz-feldspathic gneiss with thin intercalations of amphibolites, cordierite-sillimanite-garnet paragneiss, oxide-facies banded iron formation, calcsilicate rocks, marbles, olivine marbles and quartzites (Jardim de Sá et al. 1982, D'el-Rey Silva 1984, 1985). Gneisses of the crystalline basement possibly do occur within this unit, once parts of the Curaçá Valley terrane display $\mathrm{Rb}-\mathrm{Sr}$ Archean ages (Brito Neves et al. 1980, Lindenmayer 1981). However, the intense and very ductile polyphase deformation that affected the area has precluded the identification of any basement-cover diagnostic feature.

The second unit consists of 10's to 100's m - sized bodies of $\mathrm{Cu}$-poor or simply barren gabbros, gabbronorites, leucogabbros, together with Cu-rich hypersthenites, melanorites and norites. The Caraíba orebody (in the centre of Fig.2), as well as some other bodies in the Curaçá Valley, intrudes gneisses and the calcsilicate rocks. The third unit mostly comprises migmatitic gneisses and syn-tectonic granitoid intrusions $\left(\mathrm{G}_{1}\right.$ and $\left.\mathrm{G}_{2}\right)$ consisting of grey tonalites and granodiorites (Jardim de Sá et al. 1982). Apart from $\mathrm{G}_{2}$, that are far more common around Caraíba, most of the rocks above exhibit an amphibolite-facies regional metamorphic banding $\left(\mathrm{S}_{1}\right)$ that commonly encloses sub-parallel $1 \mathrm{~mm}-1 \mathrm{~cm}$ up to 1m-thick, sheet-like layers of quartz-feldspathic or simply feldspathic rocks (Fig.3A-B) indicative of an intense syn- $D_{1}$ migmatisation.

Structures and metamorphism $S_{1}$ is overprinted by two other foliations $\left(S_{2}\right.$ and $\left.S_{3}\right)$, all being associated with mesoscopic folds. $F_{1}$ folds are generally of $10 \mathrm{~cm}$-scale, rootless and intrafolial relative to $S_{1}$. The $F_{2}$ folds (and $S_{2}$ ) are rare and are mostly seen in localised outcrops of the more felsic lithotypes, together with examples of 10-100 cm-sized Ramsay's (1967) type 2 of $F_{2}-F_{3}$ fold interference pattern (Jardim de Sá et al. 1982, D'el-Rey Silva 1984). F $F_{3}$ folds are non-cylindrical, cm- up to km-sized, generally tight, asymmetric, E-verging, and their axial planes trend nearly N-S and $\operatorname{dip} 70^{\circ}-75^{\circ} \mathrm{W}$. The fold axes $\left(\mathrm{B}_{3}\right)$ are sub-horizontal and plunge either to northerly or southerly directions, such as the regional scale Caraíba antiform (Fig.2). $\mathrm{S}_{3}$ is a typical mineral foliation mostly defined by biotite, hornblende and strongly flattened quartz and feldspars, but the non-mica minerals display a prolate geometry and define a penetrative $\mathrm{L}_{3}$ mineral stretching lineation parallel to $\mathrm{B}_{3}$.

All the lithostratigraphic units in the Curaçá Valley are cross-cut by a swarm of N-S trending $10 \mathrm{~cm}$ - tens of metres thick, and up to some km-long, reddish pink alkaline granites $\left(G_{3}\right)$ emplaced parallel to and commonly displaying the $S_{3}$ foliation, and cutting across the fold hinges of mesoscopic $F_{3}$ folds. Abundant cross-cutting field relationships indicate that $\mathrm{D}_{3}$ was largely assisted by $\mathrm{G}_{3 \mathrm{a}-\mathrm{d}}$ early- syn- and late- tectonic granite magmatism (Fig.2). The Surubim and Vermelhos hypersthenite-norite orebodies, situated in the central and in the northern part of the Curaçá Valley, are both perforated by these granites, as demonstrated by 1,000's m of drill cores.

As a result of this evolution, the Caraíba orebody is a tight, non-cylindrical $F_{3}$ synform part of the western limb of the regional-scale Caraíba $F_{3}$ antiform (as in the vertical cross section at the bottom of Fig. 2; D'el-Rey Silva 1984, 1985). The Caraíba antiform itself is part of a double plunging fold that trends nearly N-S throughout the whole Curaçá Valley (Gaál 1982 a,b).

Xenoliths of hornblende-bearing basic rocks found within $\mathrm{G}_{1}-\mathrm{G}_{2}$ granitoids throughout the Curaçá Valley display a $1 \mathrm{~cm}$-thick, orthopyroxene-rich, halo of metamorphic dehydration that allowed Lindenmayer (1981), Jardim de Sá et al. (1982) and D'el-Rey Silva $(1984,1985)$ to establish an amphibolite-granulite-amphibolite sequence of metamorphism associated with the $D_{1}-D_{3}$ events. The peak of metamorphism reached $750^{\circ} \mathrm{C}-800^{\circ} \mathrm{C}$ (Figueiredo 1980,1981 ) and pressures of 6-8Kbar (Bello 1986).

\section{GEOLOGY OF THE CARAÍBA OREBODY Intro-} duction The Caraíba orebody is divided into a southern part (the open pit of the Mineração Caraíba LTDA) and a northern part belonging to Companhia Vale do Rio Doce (CVRD; Fig.2). The sub-surface continuity between these parts is widely demonstrated by underground galleries and more than $100,000 \mathrm{~m}$ of diamond drill holes made along several E-W trending cross sections $45-50 \mathrm{~m}$ and $22.5 \mathrm{~m}$ apart from each other across the property boundary and the orebody itself (Ferreira et al. 1978, Lindenmayer et al. 1984, D'el-Rey Silva 1984).

The orebody had originally $\approx 106 \times 10^{6}$ tons of ore, with average grade of $1,37 \% \mathrm{Cu}$. About $10 \times 10^{6}$ tons of this ore, with $\approx 1 \%$ average $\mathrm{Cu}$ grade, are still in the part belonging to CVRD. About 54.5 million tons of ore with $1.03 \% \mathrm{Cu}$ average grade have been exploited from surface and underground mining operations in Caraíba, from 1978 up to the last day of 1996. The open pit has now 19 benches $15 \mathrm{~m}$-high and is near to exhaustion and should be closed by the end of 1998. Proved reserves of about 42 million tons of ore with $1.82 \% \mathrm{Cu}$ average grade remain in the Mineração Caraíba property, sufficient for a further 12 years of operation at the current level of underground production.

Chalcopyrite and bornite occur disseminated and/or in irregular masses, or local veins, all hosted in $\approx 1 \mathrm{~mm}$-grained hypersthenites, melanorites and norites, part of a sequence also containing $\mathrm{Cu}$-poor gabbros, gabbro-norites and minor anortosites. The sequence is strongly deformed and disrupted, but forms a continuous orebody sub-concordant with and enclosed in a set of gneisses, orthogneisses, supracrustal rocks and a mafic complex (fine-grained gabbros, norites). Mandelta (1982) identified peridotites and olivine pyroxenites in contact with the hypersthenites, in drill cores, whereas Oliveira (1990) described some fragments of these rocks and gabbros, probably indicating original igneous breccia preserved in the orebody. $\mathrm{A} \approx 1 \mathrm{~km}$-long, $\approx 100 \mathrm{~m}$-wide, nearly $\mathrm{N}-\mathrm{S}$ trending and sub-vertical body of Cu-barren serpentinite and garnet pyroxenite crops out close to the western margin 


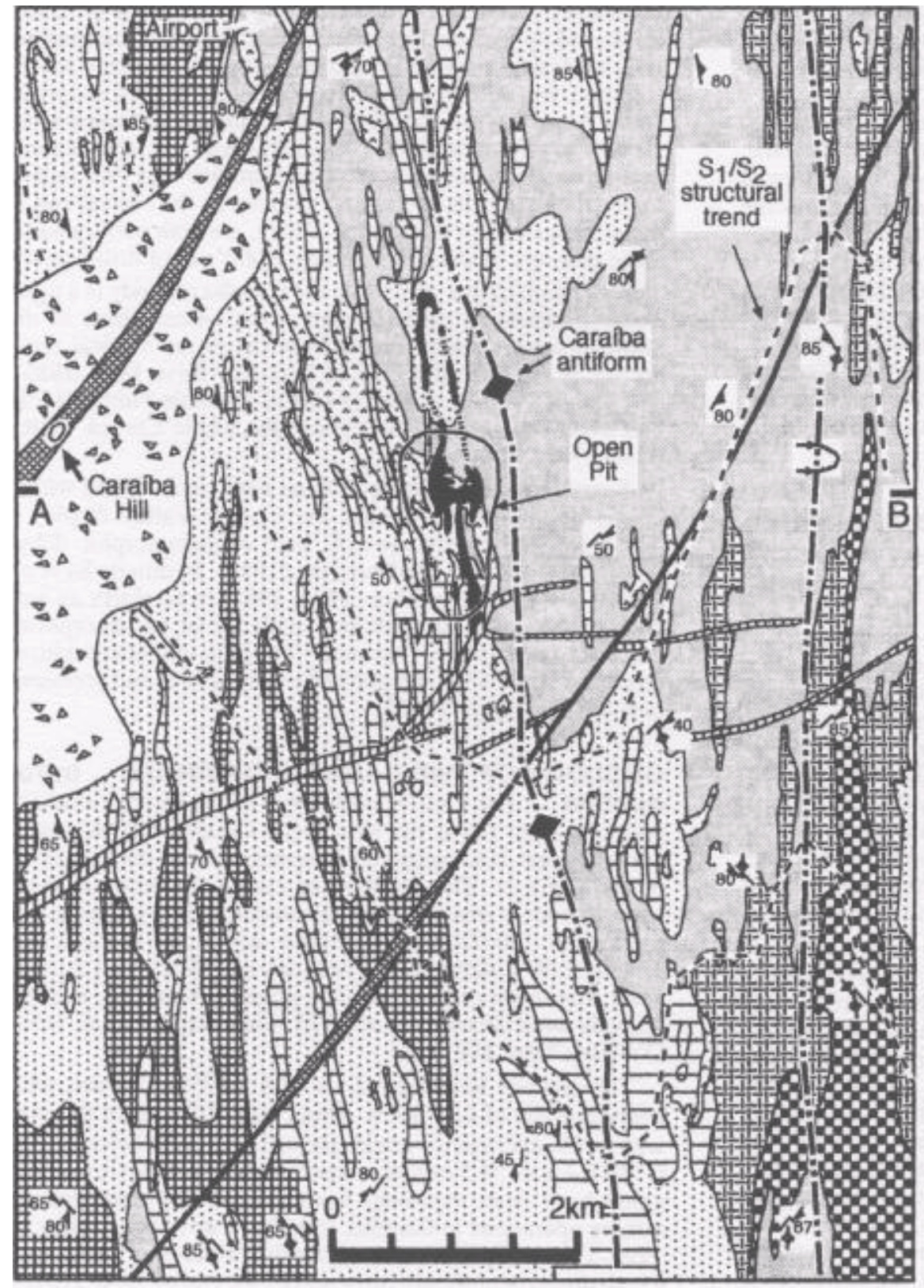

\section{MESOZOIC-CENOZOIC \\ ${ }_{4}^{\nabla} \Delta$ Quartz-vein debris

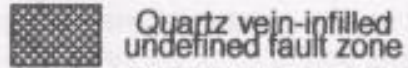

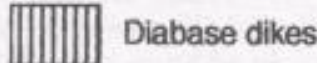

(ARCHEAN)- PALEOPROTEROZOIC

Syn-late $\mathrm{F}_{3}$ granites $\left(\mathrm{G}_{3 \mathrm{~d}}\right)$

䎴冊 Syn- $F_{3}$ granites $\left(G_{3 c}\right)$

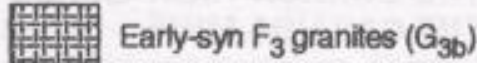

188. Early- $\mathrm{F}_{3}$ granites $\left(\mathrm{G}_{3 \mathrm{a}}\right)$

$\square$ Migmatitic gneisses and

Cu-bearing hiperstenites,

melanointes, norites

$\therefore$ Basic rocks: gabbros,

Supracrustal Sequence

Ore Trend $\% \mathrm{~s}_{1} / \mathrm{S}_{2}, \mathrm{~s}_{3}$

$n \leq F_{3}$ minor folds

$\mathrm{F}_{3}$ folds

¿. Overturned Sinform

Antiform

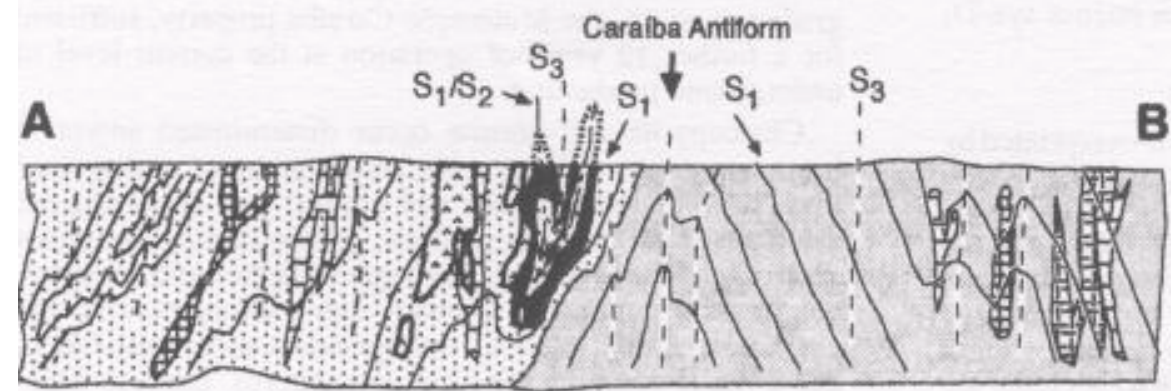

Figure 2 - Simplified geological map of the Curaçá River Valley high grade terrane in the vicinities of the Caraiba open pit shown in the centre. Based on a 1:10,000 scale geological mapping by D'el-Rey Silva (1984). See details in the text. 

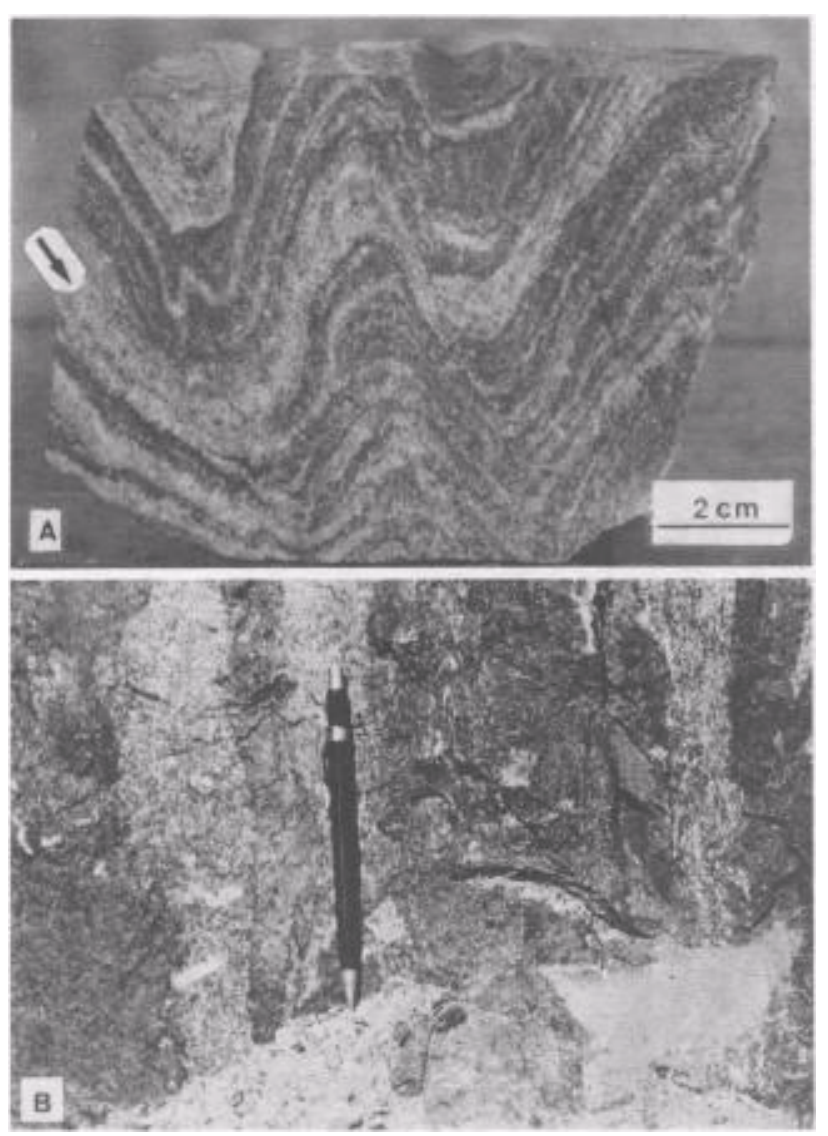

Figure 3 - Amphibolite-grade $S_{1}$ metamorphic banding in the basic gneisses that host the Caraiba orebody $(\boldsymbol{A})$ and in the orebody itself $(\boldsymbol{B})$. The arrow in $(\boldsymbol{A})$ points to sheet like quartz-feldspathic layers intruded sub-parallel to the metamorphic banding and also affected by $\mathrm{F}_{3}$ folds and a penetrative axial plane $S_{3}$ foliation marked by dark spots of biotite and hornblende. Photograph of the banding in the orebody (B) is from the bottom of one the benches at the Mine (see the $12 \mathrm{~cm}$-long pencil for scale). Note the sub-vertical, irregular contacts between dark layers of hypersthenite and lighter layers of hypersthene-bearing feldspathic rocks (leuconorites). Both the layers display an internal, layer-parallel metamorphic banding, though it developed much more in the leucocratic layers.

of the open pit (Ferreira et al. 1978, D'el-Rey Silva 1984; omitted in Fig.2 for simplicity).

The walls of the four first benches of the Caraíba open pit $(440 \mathrm{~m}, 425 \mathrm{~m}, 410 \mathrm{~m}$ and $395 \mathrm{~m})$ were mapped in a $1: 1,000$ scale simultaneously with the opening of the lower bench $(395 \mathrm{~m})$, so the orebody could be followed as the walls advanced every $20 \mathrm{~m}$, blast after blast. Figure 4 is a summary geological map of the Caraíba open pit, based on the results of such detailed mapping (D'el-Rey Silva 1984, 1985).

Orebody geometry, surrounding lithotypes, contacts The outcroping part of the orebody displays an ameboid shape with a central, E-W trending layer that dips abruptly to the north and bends northwards and southwards at its ends. From the central part the orebody splits into four layers trending N-S and dipping sub-vertically, generally to the west (Fig.4). Two of these layers stretch continuously northwards (the eastern of these layer continues to the north at lower levels, as has been demonstrated since the first years of mining prospecting and development. The other two N-S trending layers form a narrower corridor and trend southwards from the central body. Between the bench 380 and the limit of the open pit, the southern part of the largest of these layers consists of $0.5 \mathrm{~cm}$-grained $\mathrm{Cu}$-poor hypersthenites (Ferreira et al. 1978, Mandetta 1982, D'el-Rey Silva 1984) indicating different stages in the formation of the orebody.

The orebody is closely associated with a set of $\mathrm{Cu}$-barren gabbros, gabbronorites and anorthosites, but also occurs in contact with the supracrustal sequence (mostly gneisses), to the west, and a sequence of well-banded mafic gneisses to the east (Fig.4). The contact of the orebody with Cu-barren basic rocks, and that of these with the mafic gneisses is generally gradational, being marked by increasing amounts of layeringparallel feldspathic layers. $G_{3}$ granites crop out mainly in the southern part of the open pit.

The contact with the gneisses on both the $\mathrm{W}$ and $\mathrm{E}$ sides is generally sub-vertical and is commonly marked by zones of intense ductile deformation and migmatisation (Fig.5A). This contact was overprinted by NNW and NNE trending zones of ductile shearing developed late in the evolution of the area, whereby the narrow pyroxenitic layers were retrometamorphosed into biotitites (D'el-rey Silva 1984, 1985). Several of these shear zones do not appear on the map for simplicity. Chalcopyrite and bornite were remobilised into shear zonecontrolled small veins, even within the orebody and also into the adjacent country rocks. However, such zones did not imply any large displacement of the mineralised layers, although they commonly show a sub-horizontal striae lineation on the biotite-chlorite foliation planes. Rocha (1987) described small-scale structures indicating that $\mathrm{F}_{3}$ was probably associated with sinistral transcurrent movements.

Structures in Caraíba The $\mathrm{Cu}$-bearing rocks display a clear Si metamoiphic banding (Fig.3B) seen generally subvertical either near the contact (Fig.5A) or inside the orebody itself, particularly within the melanorites, which consist of layers of hypersthenite intercalated with banded norites and leuconorites (Fig.5B). Isoclinal folds of $10 \mathrm{~cm}$ scale have been found affecting melanorite layers within the $S_{1}$ planes. Both the orebody contact and $S_{1}$ are affected by $10 \mathrm{~cm}-10$ $\mathrm{m}$-size $\mathrm{F}_{3}$ folds, the hinges of which are invaded by feldspathic (quartz) melts late on folding (Fig.5C), and by $\mathrm{G}_{3}$ granites, as will be shown ahead in this paper. The $S_{2}$ foliation has not be seen in the Mine, but $\mathrm{F}_{2}$ folds with $\mathrm{E}-\mathrm{W}$ trending, sub-vertical to sub-horizontal axes, $\mathrm{F}_{2}-\mathrm{F}_{3}$ boomerangs, and an E-W trending, $\mathrm{S}_{2}$ mineral foliation of biotite and orthopyroxene, clearly exist around the Mine (several color photographs in D'el-Rey Silva 1984). The best examples are in a large outcrop about 1 $\mathrm{km}$ eastwards of the open pit, in the eastern limb of the Caraíba antiform (Fig.4). Moreover, the horizontal and vertical geometry of the orebody implies that $\mathrm{S}_{1}$ was affected by two further folding events $\left(\mathrm{F}_{2}\right.$ and $\left.\mathrm{F}_{3}\right)$.

$\mathrm{S}_{3}$ is penetrative in the surrounding gneisses and basic rocks, which display plenty of $\mathrm{F}_{3}$ folds with axes plunging gently, generally in southerly directions (Fig.4), and also in thinner hypersthenite layers affected by $\mathrm{F}_{3}$ folds (Fig.5C), but it commonly dies out within the inner parts of thicker hypersthenite layers (Fig.5D). Actually not only the massive $1-10 \mathrm{~m}$ thick hypersthenite layers, but also the boudins and blocks of basic rocks within the migmatites and the $\mathrm{G}_{2}-\mathrm{G}_{3}$ granitoids, are practically $\mathrm{S}_{3}$-free (several color photographs in D'el-Rey Silva 1984). Since 1982-1984 this has been interpreted as a simple matter of differential rheology among layers of different composition, as the hypersthenites occur disrupted on outcrop scale, on scale of bench walls and on the scale of the orebody layers.

During mining grade control was provided by analysis of cuttings from the thousands of blast-holes. The $5 \mathrm{~m}$ square 


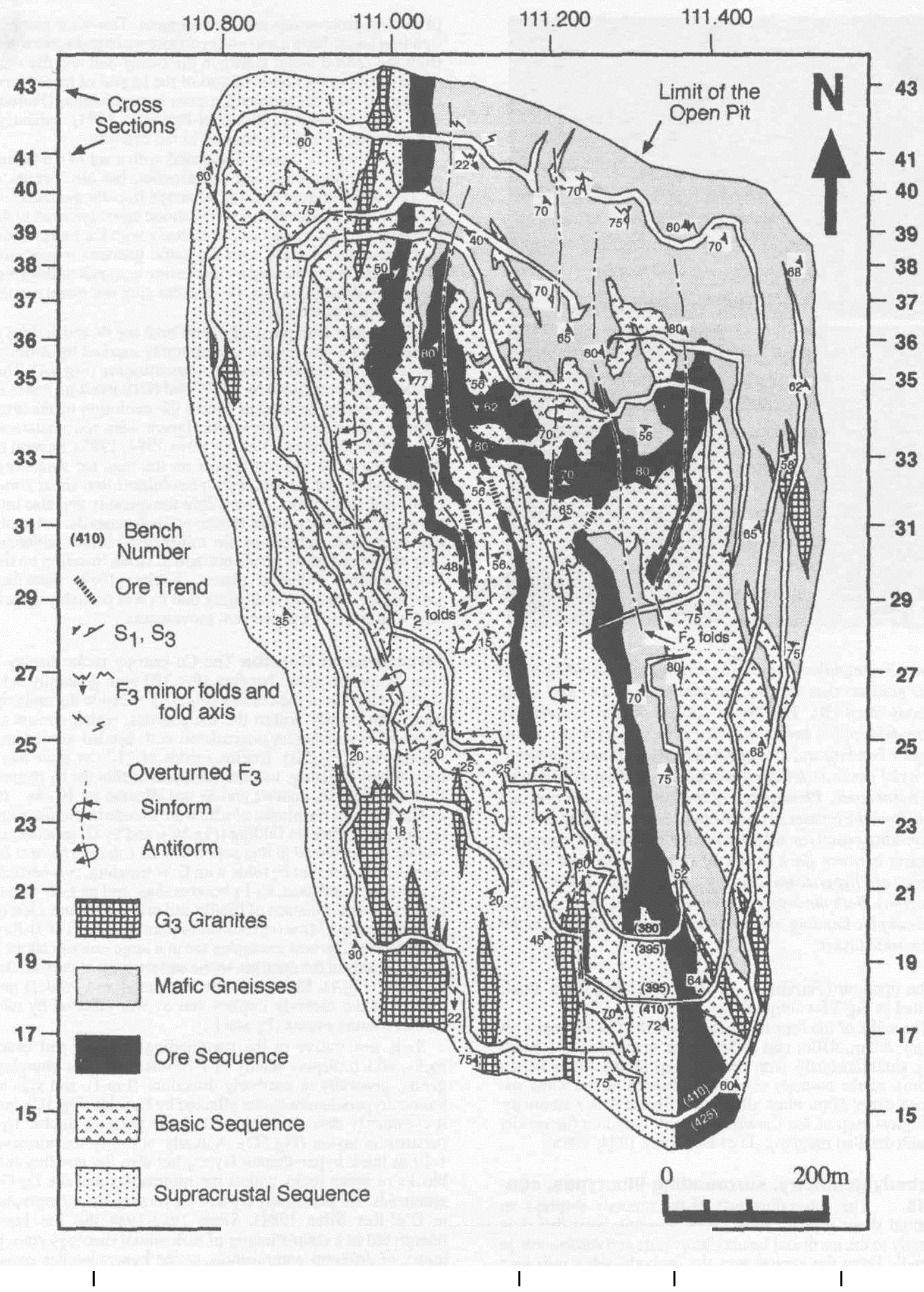

Figure 4 - Simplified geological map of the Caraiba open pit, based on the 1:1,000 scale mapping carried out from 1980 to 1984 in the first four benches (see benches 425, 410, 395 and $380 \mathrm{~m}$ above sea level). From D 'el-Rey Silva (1984, 1985). See details in the text. 

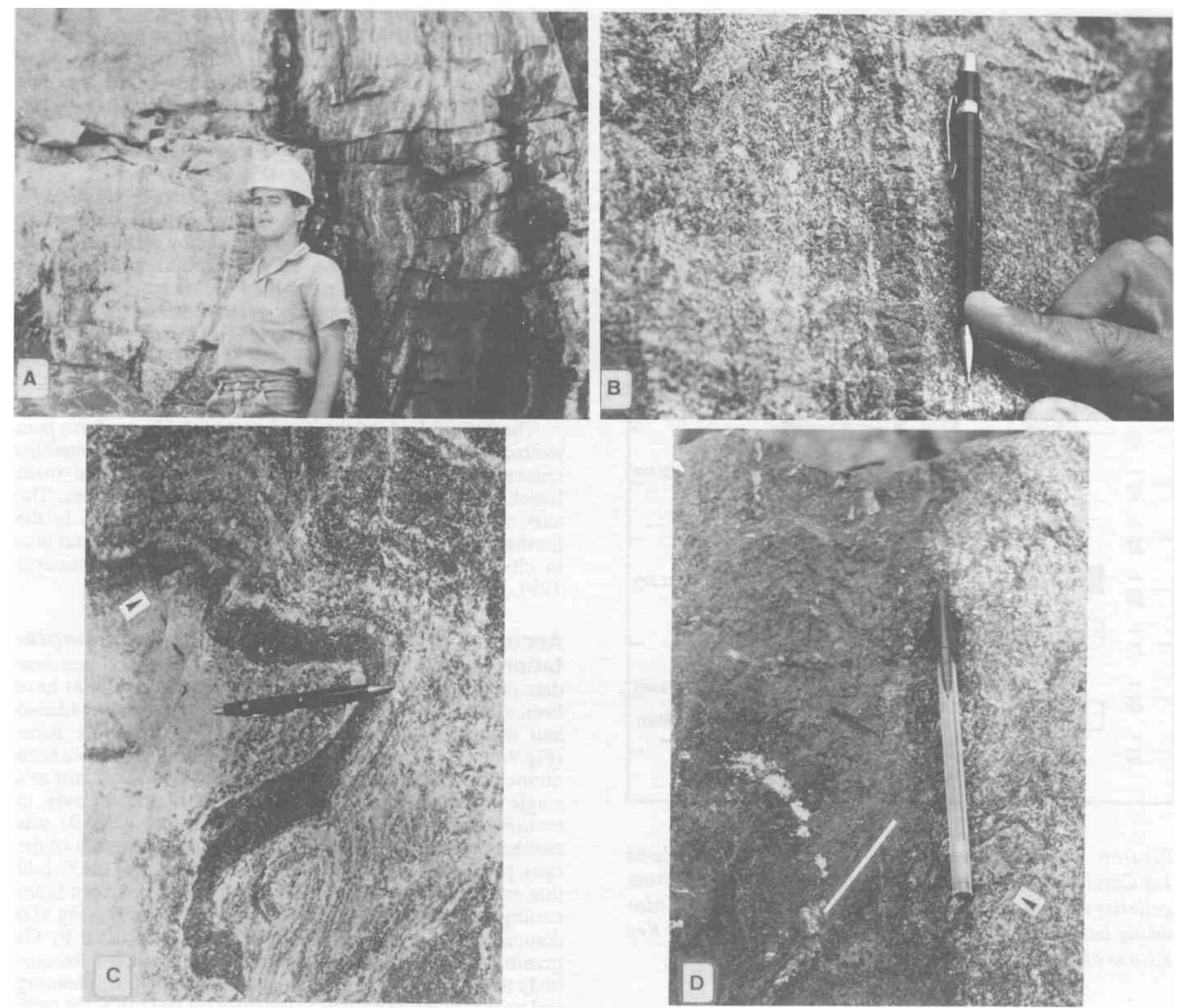

Figure 5 - Sub-vertical contact between dark pyroxenitic layers to the right and gneisses, marked by a Im-thick zone of intense migmatization, in the vertical walls of the Caraiba Mine $(\boldsymbol{A})$. $S_{1}$ metamorphic banding within the orebody, defined by irregular layers of pyroxenite within norite-leuconorites (B). FI folds affecting melanorites with the $S_{3}$ foliation cutting through the thin hypersthenite layer, between the arrow and the $12 \mathrm{~cm}$-long pencil $(\mathbf{C}) . S_{1}$ banding affected by $S_{3}$ (arrowed) cutting through the irregular contact and dying out inside the pyroxenitic layer to the left (D). Even so, $S_{3}$ can be traced inside this layer, close to the bottom of the $12 \mathrm{~cm}$-long pencil, parallel to the white bar.

grid pattern for these was meticulously surveyed prior to drilling of each shot. Such grade control is a key tool for separating ore from waste and in mine planning. The contour lines drawn for several intervals of $\mathrm{Cu}$-content on each bench, using this grade information (Fig.20A-C and 21 in D'el-Rey Silva 1984), from such accurately controlled close-spaced drill holes with such an accurate control of position, mimic entirely the surface shape of the orebody and demonstrate the occurence of several 10-100's m long, Cu-rich boudins surrounded by parts of lower $\mathrm{Cu}$ grade. Such rich bodies lie along $\mathrm{S}_{1}$, and also change trend from N-S to E-W in the central part of the orebody.

The F2-F3 Caraíba mushroom Together, the northern and southern parts of Caraíba form an extremely tight mushroom (Fig.2). Such map geometry (see also inset in Fig.6) continues at depth, as the geometry shown in the first four benches of the open pit is mirrored in the detailed maps drawn from mapping of the galleries and logging of drill holes every $20 \mathrm{~m}$ in the underground mine. Again, the continuity of the orebody through the limit of the property has been proved at these lower depths, by cross-sections $39-45$ and others in CVRD's property.

The hinges of the $F_{2}$ folds (Fig.4) could be interpreted because the termination of the mineralised layers in the central part of the orebody builds $60 \mathrm{~m}$-high sub-vertical tubes of ore, between benches 440 and 395, and these tubes could be compared with the sub-vertical axis of $F_{2}$ folds, whereas the shape of the whole orebody itself could be compared with $\mathrm{F}_{2} \mathrm{XF}_{3}$ mushrooms seen in the field (D'el-Rey Silva 1984, 


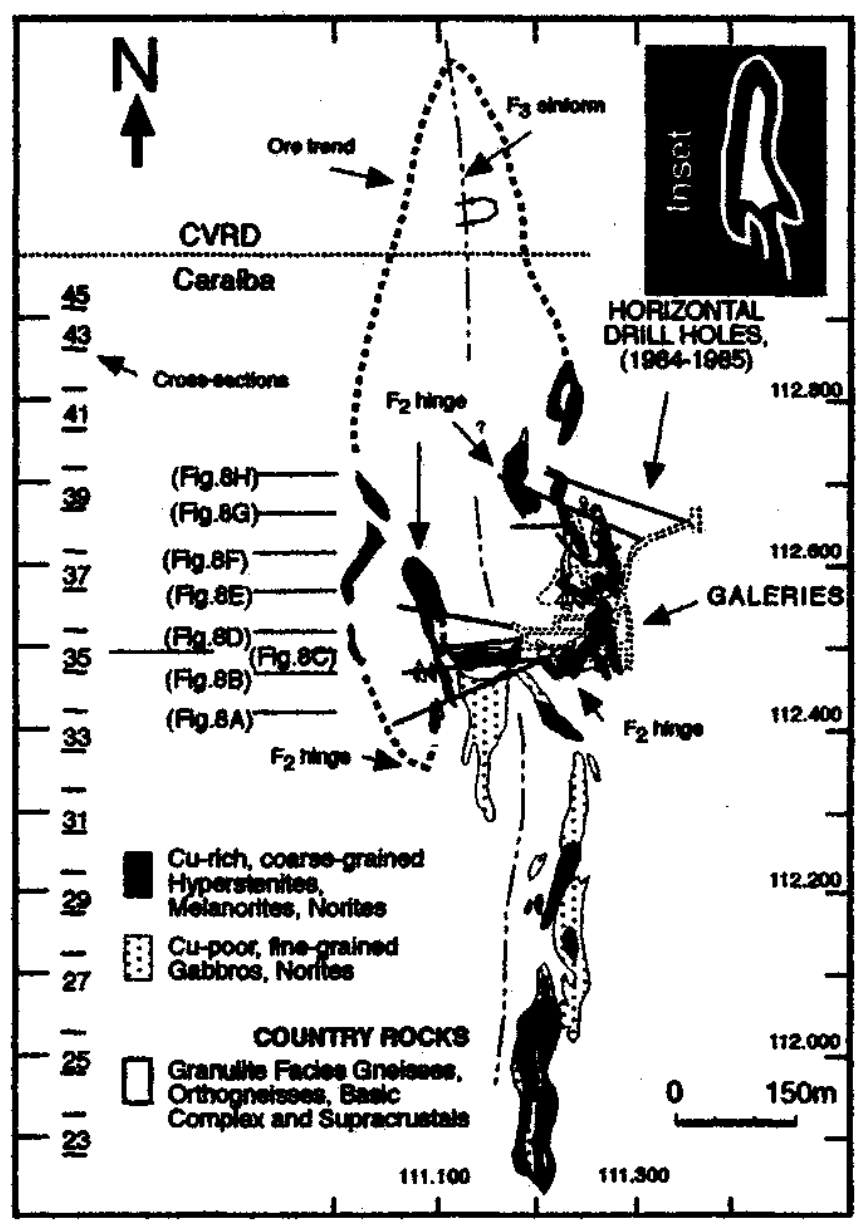

Figure 6 - Simplified map of the Cu-bearing rocks on sub-level 1 of Caraiba (320 m below surface) elaborated with data from galleries and horizontal bore holes on the sub-level, and also taking into account vertical cross-sections 23-43 (D'el-Rey Silva et al. 1994). See text for details.

1985). Because the $F_{2}$ fold hinges are continuous downwards (Fig.6), D'el-Rey Silva et al. (1988) could introduce the 3-D mushroom (Fig.7) that has been successfully checked afterwards. No single unsuitable geometric model can survive for more than six months in a mine, so huge is the amount of data generated by the daily operations.

The large-scale structure of the orebody (Fig.7) allows to understand its southern, central and northern parts both horizontally and vertically. For example, to the south of cross-section 31 , the orebody consists of N-S trending, sub-vertical layers that were disrupted around the hinge zone and along the limbs of the main $\mathrm{F}_{3}$ synform.

The central part of the orebody consists of E-W and N-S trending, high angle dipping layers between sections 32 and 37. The original $\mathrm{F}_{2}$ folds were probably sub-recumbent with sub-horizontal axis trending E-W, and were affected by $\mathrm{F}_{3}$ folds with axis dipping gently to the south, so the $F_{2}$ folds axes were brought to the vertical position, being still sub-horizontal only at depths, around the hinge of the large $F_{3}$ fold (Fig.7). As a consequence, the central part of the orebody contains most of the ore reserves and displays a complex geometry in cross-sections.

Due to the lack of a clear stratigraphic marker within the orebody, the interpretation of cross sections 32 to 37 was always difficult, but more data from many diamond drill holes and galleries, allowed new adjustments (Fig.8A-H). Thus, the boomerang geometry interpreted in the cross-sections of the central part (see inset in Fig.8A-B) was already a modification on those elaborated in 1984, 1985, because of the new data available in 1988. Such structure has been demonstrated afterwards by following the mineralised layers at the time of their exploitation from one bench to another, in the open pit, along successive cross sections (Fig.8C-E).

To the north of section 37 (Fig.8E) the orebody displays again the simpler geometry of an asymmetric $\mathrm{F}_{3}$ synform, the hinge zone of which has been perforated by many drill holes at depth, as in sections 38, 39 and 40, during recent years (Fig.8F-H). These indicate that the $\mathrm{F}_{3}$ fold axis plunges to the north in that part of the orebody and the outer arc of the hinge reaches $-300 \mathrm{~m}$ below the sea level $(750 \mathrm{~m}$ below surface) in section 40/1996 (Fig.9H), but goes as deep as 1,000 m below surface in other sections to the north, still in the Mineração Caraíba property.

The eastern limb of the blind part of the Fa synform is in contact with highly strained calcsilicate rocks and marbles commonly displaying a N-S trending sub-horizontal striae lineation, as seen in underground sites and bore holes. The axis of the Caraíba synform plunges to the south in the northern end of the orebody, where the hinge crops out also in close association with calcsilicate rocks (Lindenmayer 1981,Lindenmayer et al. 1984).

Accuracy of cross-section drawing and interpretation All the cross-sections drawn to incorporate new data produced up to 1988 (D'el-Rey Silva et al. 1988) have been checked carefully afterwards using new data produced and incorporating all the $\mathrm{S}_{1}$ foliation data in the cores (Fig.9A), along the bore holes. These foliation data have been omitted for the sake of clarity (Fig.8A-H). However, just as a single example, the upper central part of the orebody in sections drawn in 1988 (see white stars in Fig.8A-B) was checked by a fan of bore holes starting on the bottom of the open pit (Fig.8C-D), confirming the hinge zone of the $\mathrm{F}_{3}$ fold that refolds a limb of $F_{2}$ fold. The cores of two bore holes cutting through such $\mathrm{F}_{3}$ fold in section 36/1994 (Fig.SD) demonstrate that the hinge is disrupted and infilled by 63 granites. Brittle fracturing and boudinage disrupted the orebody throughout the structural evolution, so mining planning and underground exploitation are difficult tasks in some parts of the mine. Overall, the complexity of the orebody combined with the disruption of the Cu-rich layers in all scales has imposed the need for caution in mining planning and has contributed to restrict profits (D'el-Rey Silva 1992).

The trend of $S_{1}$ along several bore holes that prove the hinge zone in section 35-36/1996 (Fig.9B) also confirms the geometry and the structural evolution of the orebody. For precaution against the lack of control on rotation of the drill cores, the edges of the cone of possible angles between $S_{1}$ and the core axis were plotted on the plane of section (Fig.9B), for $360^{\circ}$ of rotation of the core. This technique is the sole available for the case and is extremely safe in two situations that are in the majority at Caraíba: 1 - Wherever the bore holes are oriented sub-perpendicular to the external limits of the layer (such as in Fig.9B), $\mathrm{S}_{1}$ must remain sub-perpendicular to the axis of the cores; 2 - Wherever the bore holes are sub-parallel to the external limit of the layers, $S_{1}$ must remain sub-parallel to the axis of the core. In such situations, for any rotation of the core in space, the $\mathrm{S}_{1}$-core axis observed angle remains almost the same on the plane of section.

For both situations the contact of the orebody in cross-section must be parallel to the bisectrix of the angle of the cone of $S_{1}$ foliations (as in Fig.9B). Such a relationship has also been tested in the limbs of the Caraíba synform. As the limbs are proved to be sub-vertical by a fan of many, closely spaced 


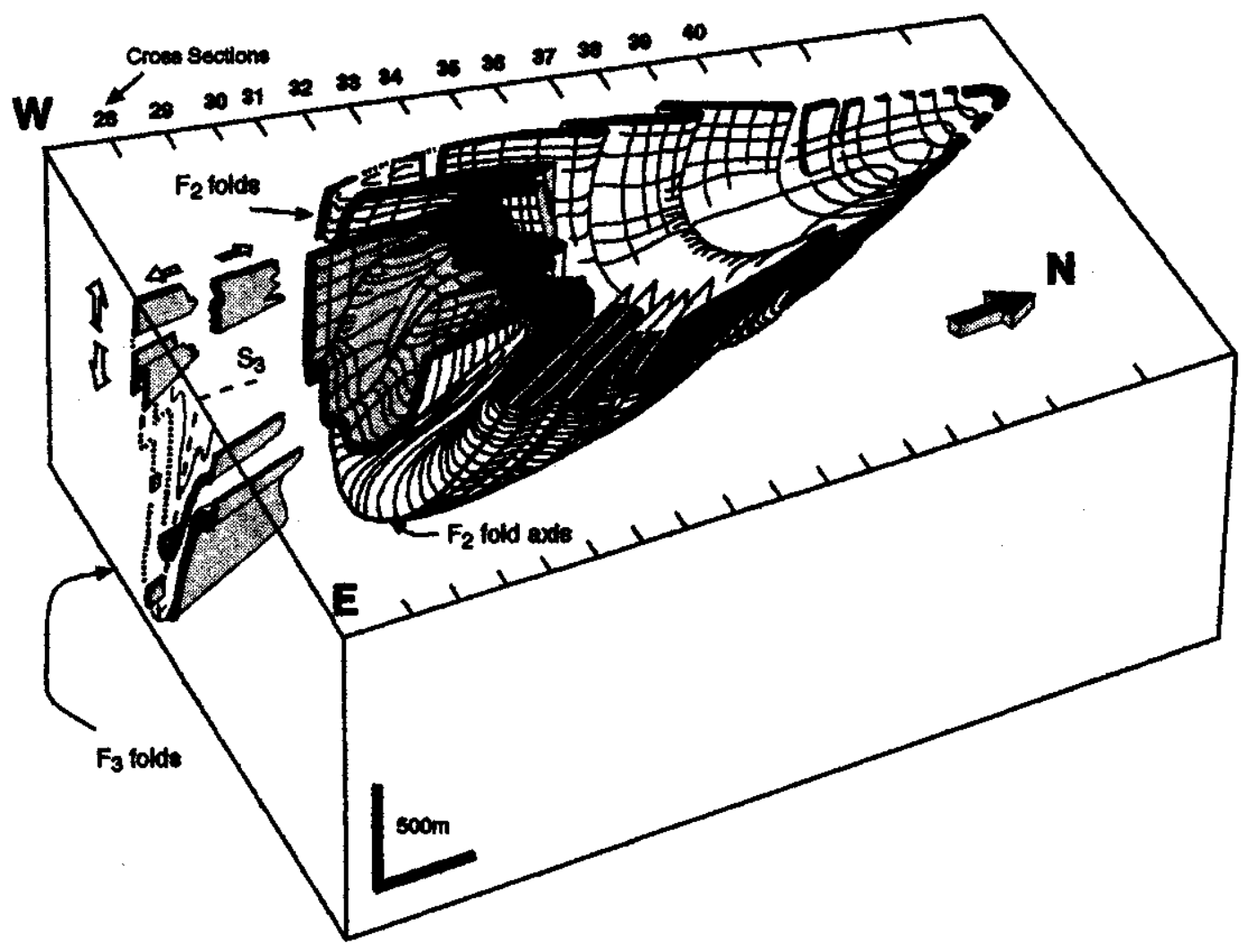

Figure 7-3-D representation of the Fix FS mushroom that controls the whole Caraíba orebody (From D 'el-Rey Silva et al. 1988). See details in the text.

bore holes on each cross-section (e.g. Fig.8G-H), $\mathrm{S}_{1}$ is mostly at high angles with the axis of the cores in sub-horizontal holes.

The fact that these relationships have been observed in cross-sections throughout the mine, exactly where hinge zones and fold limbs are expected, demonstrates the validity of the technique used to overcome the lack of orientation of the drill cores. Currently, the amount of data is so large in many sections that the technique is almost unnecessary, as the limits and boomerang geometry of the orebody are obtained directly from the fan of bore holes in cross-sections.

AGE OF THE D $_{1}-D_{3}$ DEFORMATION IN THE CURAÇÁ VALLEY TERRANE D'el-Rey Silva (his Fig. 15,1984 ) used a plane table to map at 1:100 scale a nearly $1,000 \mathrm{~m}^{2}$ flat-lying outcrop of a foliated tonalite affected by numerous $0.5-2 \mathrm{~m}$ scale $\mathrm{F}_{3}$ folds, at the Caraíba airport (Fig.2). In thin sections the rock is composed of oligoclase-andesine, hornblende, biotite, orthopyroxene and clinopyroxene, minor microcline and quartz, with garnet, magnetite, apatite, and zircon as accessories; the $\approx 1 \mathrm{~cm}$-thick and discontinuous metamorphic banding or coarse mineral foliation (his Photograph 44) displays flattened crystals of feldspar, quartz, biotite, and pyroxene, whereas the penetrative $\mathrm{S}_{3}$ foliation is mostly marked by biotite, hornblende and quartz.

The tonalite intrudes layers of basic rocks (with a penetrative $S_{1}$ metamorphic banding) as deduced by tens of $\approx \operatorname{lm}$-size boudins aligned within E-W layers that were folded and disrupted by $\mathrm{D}_{3}$. After boudinage, the boudins rotated $90^{\circ}$ around the vertical axis so their longer horizontal axis lies along the N-S trending axial plane of the $\mathrm{F}_{3}$ folds. The hinge of some of these folds is cut by several intrusions of $\mathrm{G}_{3}$ granites. The tonalite is classified as $\mathrm{G}_{2}$ and its granulite-facies foliation is interpreted to be $\mathrm{S}_{2}$.

Two samples (AP-1 and AP-2) of this tonalite produced twelve fractions of zircons, whereas one zircon fraction and a monazite fraction were taken from a sample of $\mathrm{G}_{3}$ granite (GT-1) collected in the southern part of bench 440 of the Caraíba open pit. These fractions, obtained and studied by Dr. Olavi Kouvo in the Geochron Laboratory of the Geological Survey of Finland, provided the analytical data (Table 1) that plot in the concordia diagram (Fig. 10). The results were available in late 1984 but the analytical data could not be included in D'el-Rey Silva's thesis, since it was concurrently completed in Brazil.

A-F fractions of zircons from AP-1 are clearly not cogenetic and likely form two populations. The fraction with density $4.3-4.6 \mathrm{~g} / \mathrm{cm}^{3}$ was analysed three times: as such (A), HF leached (D) and abraded (F). The three points coincide within the limits of error and the age calculated according to the diffusion model is 2,334 Ma. Considering the high discordance of the points, however, this age seems not realistic and is probably too high. Fraction $\geq 4.6 \mathrm{~g} / \mathrm{cm}^{3}$ also was analysed three times, as such (B), HF leached (C) and abraded (E). The chord defined by these three points (Fig. 10) gives an upper intercept of 2,301 +/-142 (2 sigma error), which is the maximum age of the sample, with a lower intercept 1,098 Ma. The diffusion model age of the air abraded fraction $\mathrm{E}$ is $2,235 \mathrm{Ma}$ and this might be a realistic estimate. From sample AP-2 the density fraction $4.2-4.6 \mathrm{~g} / \mathrm{cm}$ was analysed six times in various hand-picked fractions. Points F-C-D-B form an array

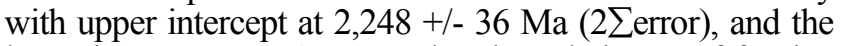
lower intercept at $256 \mathrm{Ma}$. Dark coloured zircons of fraction E give concordant results and indicate a model age 2,328 Ma. 


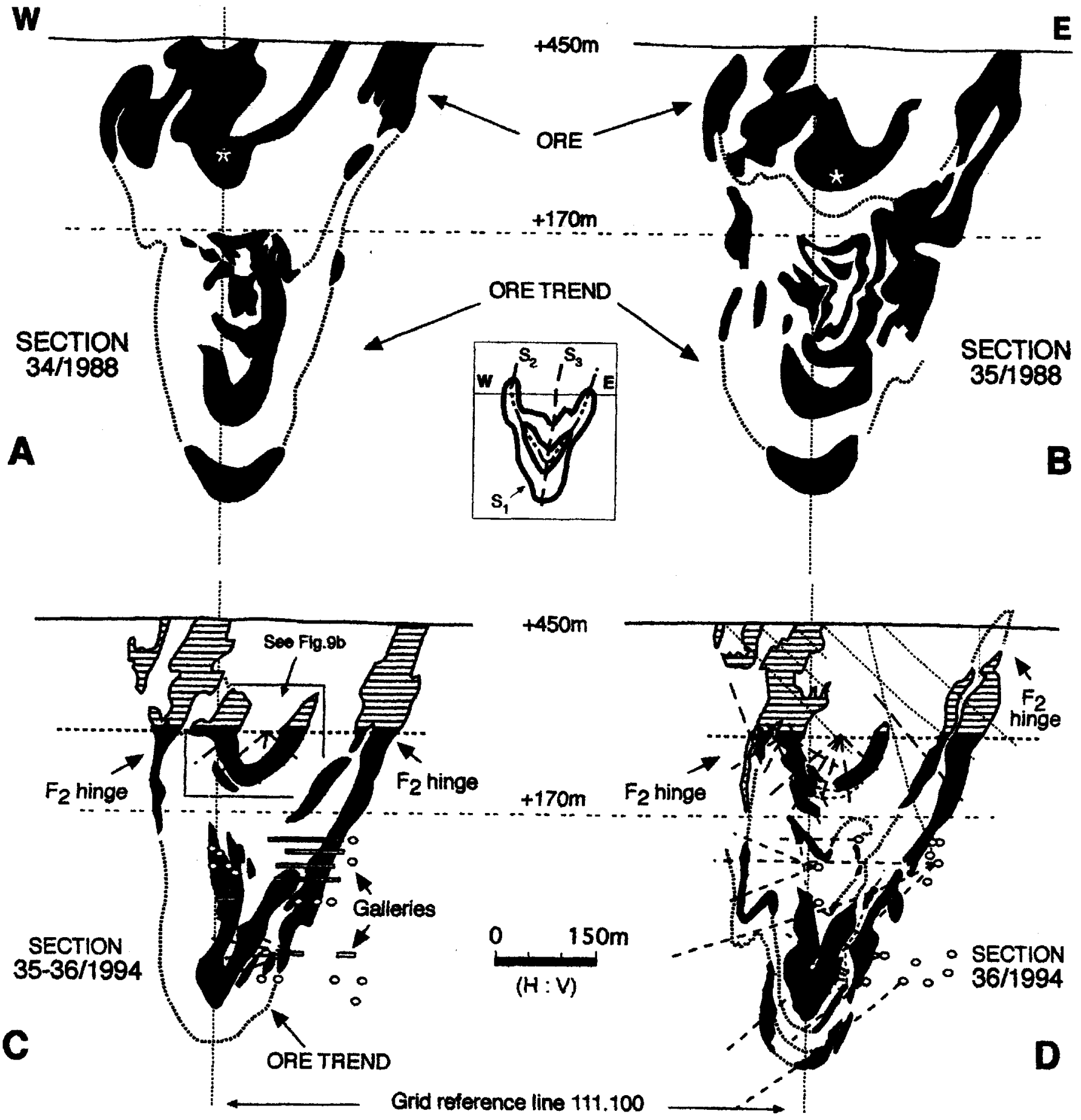

Figure 8 - Vertical cross-sections 34 and 35 (A-B) as in D 'el-Rey Silva et al. (1988). Drill holes are omitted in these sections. The white star in the hinge of the $F_{3}$, fold marks the areas of the orebody which have been detailed by intense drilling in the last years. Cross-sections 35-36, 36, 37 and 38, as in D'el-Rey Silva et al. (1994). Cross-sections 39 and 40 (G-H) incorporate new data obtained between 1994 and 1996, demonstrating the hinge zone of the Caraiba F $F_{3}$ synform, as predicted in D'el-Rey Silva (1984, 1985), however at greater depths in these sections. The surface is $450 \mathrm{~m}$ above sea level. The limit between exploited and existing ores marks the bottom of the open pit in 1994, on each section. Level 170m is the bottom projected for the open pit. The orebody is continuous horizontally and vertically, but lies below the bottom of the open pit on sections 39, 40, 41, 43. Legend for rocks and drill holes as in $\mathrm{G}-H$. 


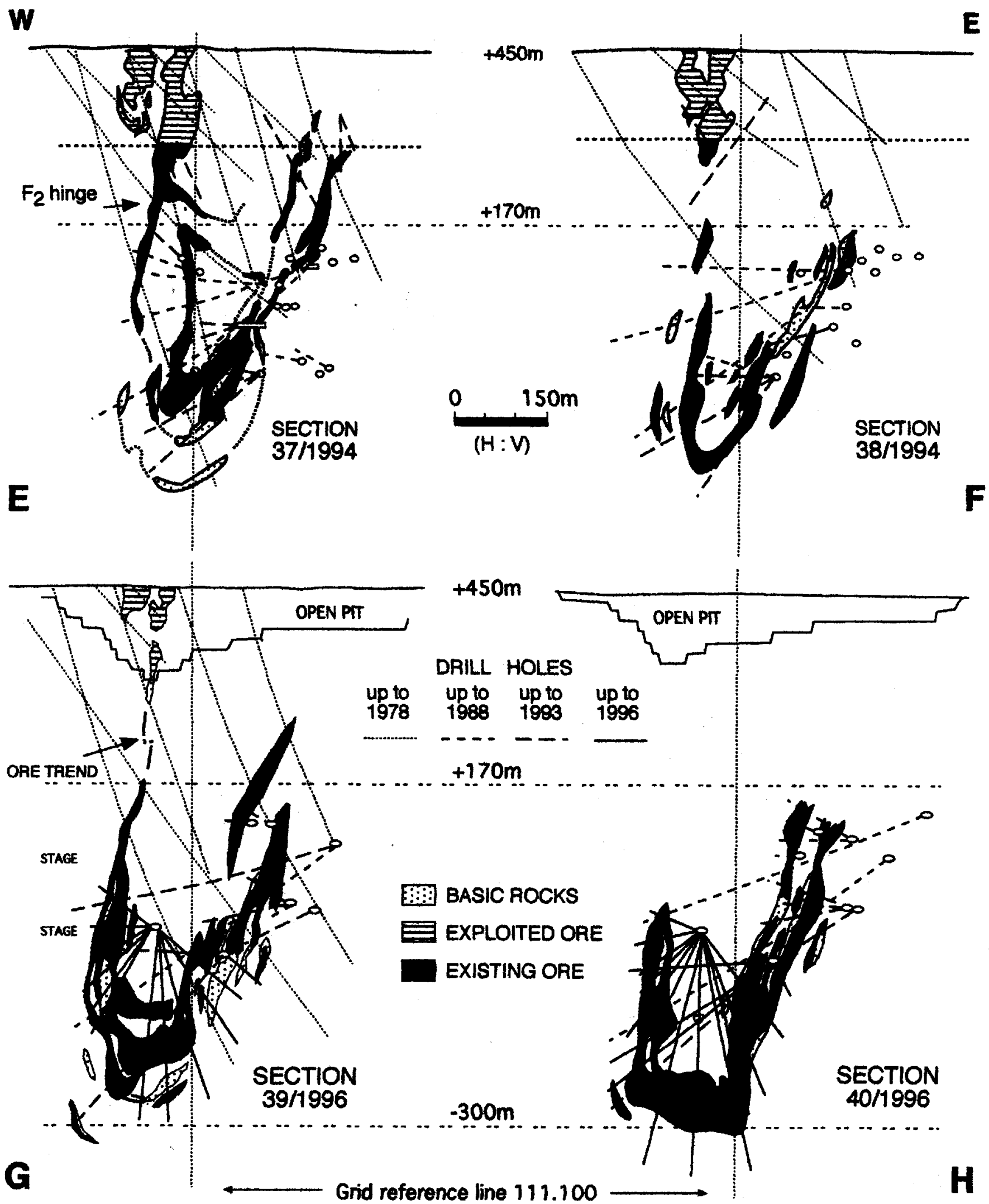

Figure 8 - continuation....

The analytical data from the single fraction of zircons of sample GT-1 plot just slightly above the discordia array of sample AP-2. The monazite, however, indicates younger generation with age $2,051+/-16 \mathrm{Ma}$ ( 2 sigma error). The data available do not give information on the nature of the mona- zite, which could be either a metamorphic mineral or product of restite crystallisation.

Anyway, the youngest granites in the Curaçá Valley are no older than 2,051 +/- $16 \mathrm{Ma}$, whereas older tonalites are no older than $2.25 \mathrm{Ga}$. The time span for the structural evolution 

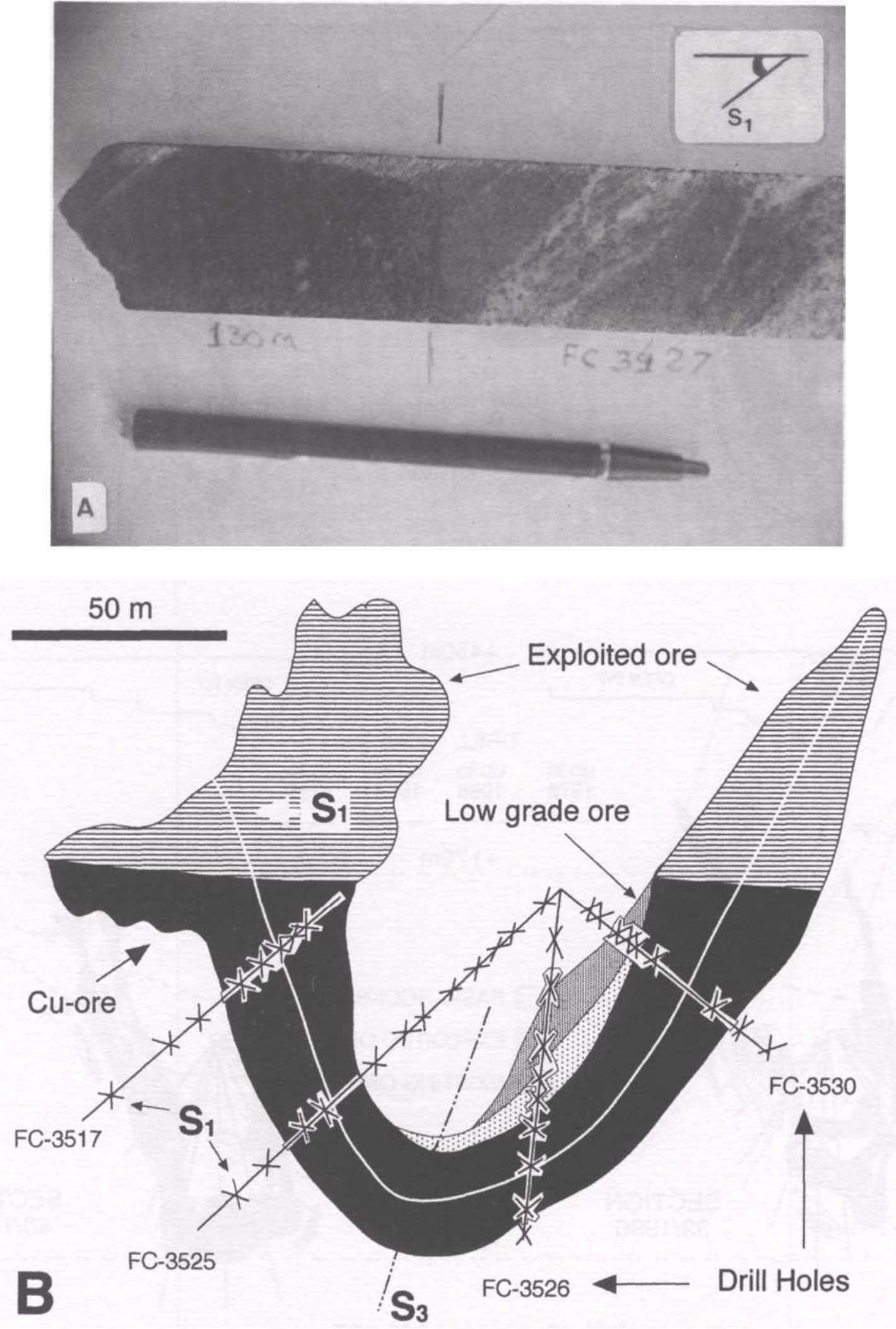

Figure 9 - Example of the $S_{1}$ metamorphic banding as seen in drill cores of banded mineralised norites and melanorites (A). The banding is distinguishable from $S_{3}$ because these structures are morphologically distinct. The angle between $S_{1}$ and the core axis is shown in the white box. The example is from $130 \mathrm{~m}$ of drill hole FC3427. The black pen is $12 \mathrm{~cm}$-long. The central part of section 35-36 (Fig.8C) is shown in (B), with the fan of drills that perforated the hinge of the $F_{3}$ synform, from the bottom of the open pit at that time. The method of plotting the $S_{1}$ foliation along the bore holes on the section plane has been adopted throughout the mine. 
Table 1 - Analytical data from samples AP -1 (A-F), AP - 2 (A-F), GT - 1 (A-B) of the surroundings of the Caraiba Cu-deposit, Bahia, Brazil. Data obtained in the Laboratory of Geochronology of the Geological Survey of Finland.

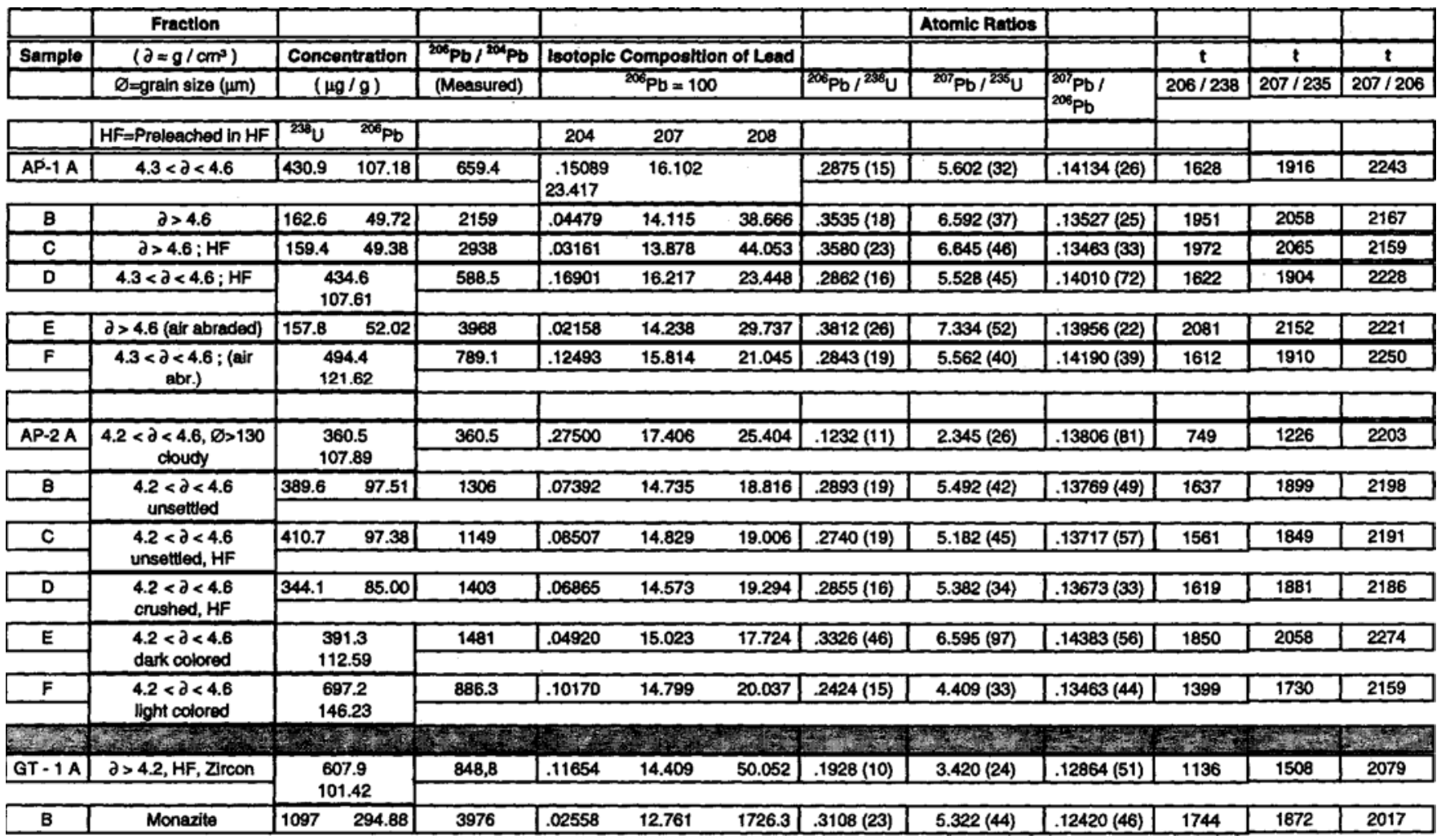

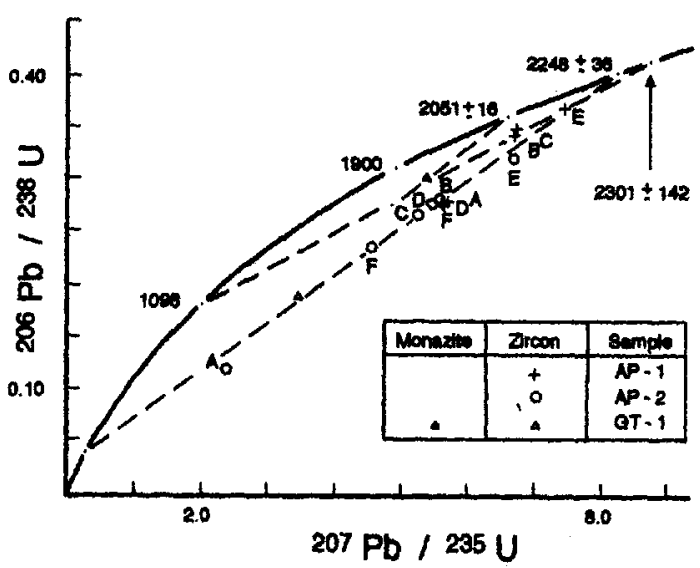

Figure 10 - Concordia diagram displaying the U-Pb ages of $G_{2}$ and $G T$, granites in the surroundings of the Caraiba Mine. Plot based on the analytical data shown in Table 1.

of the Curaçá Valley may be bracketed within 2.3-2.25 and $1.9 \mathrm{Ga}$, as discussed below.

\section{DISCUSSION Implication for the structural evolution of the Curaçá Valley terrane The $\mathrm{D}_{3}$} event was so intense and melt-assisted that $\mathrm{D}_{1}-\mathrm{D}_{2}$ structures were disrupted, rotated, brought into parallelism with 83 and obscured by migmatisation in many parts of the Curaçá Valley terrane, driving many authors working in the area into an initial dispute on the understanding of the kind of $\mathrm{F}_{2} \mathrm{XF}_{3}$ interference pattern. However, a consensus about the $\mathrm{D}_{1}-\mathrm{D}_{2}$ Ds events and the granulite facies metamorphism associated to $\mathrm{D}_{2}$ always existed.

The dispute did not last because so many data provided by the exploitation in the Mine allowed establishment of a confident geometry for the orebody based on the type 2 fold interference pattern of Ramsay (1967). Because the thick and relatively competent hypersthenite-norite layers acted as a rigid barrier to the strong $\mathrm{F}_{3}$ flattening, protecting the surrounding area, they could provide the evidence for an E-W trend of the $\mathrm{F}_{2}$ folds in the Curaçá Valley (D'el-Rey Silva 1984, 1985, D'el-Rey Silva et al. 1988).

Within the Salvador-Curacá belt, about $300 \mathrm{~km}$ to the south of Caraíba, D'el-Rey Silva (1993) and D'el-Rey Silva et al (1994) found conclusive evidence for- similar $\mathrm{D}_{1}-\mathrm{D}_{3}$ structures, all compatible with an oblique collision between two cratonic blocks, whereby an overall sinistrai transpression acted since $\mathrm{D}_{1}$ and developed $\mathrm{E}-\mathrm{W}$ trending folds due to a set of ductile lateral ramps probably because of an irregular craton margin and/or due to local rotation of the main stress field. In that area, the E-W trending $\mathrm{D}_{2}$ structures and FixFs typical mushrooms could be preserved because, during FS sinistrai transpression, parts of the belt remained partially protected around indentations of the craton margin to the west.

Fitting the orebody geometry Into the $D_{1}-D_{3}$ structural evolution Since the Mine has been mapped in detail, D'el-Rey Silva (1984) drew attention to the fact that the whole shell of the Caraíba orebody (Fig.2) trends N-S, whereas the basic rocks and gneisses outside the shell trend NW and those ones inside the shell follow both the E-W and $\mathrm{N}-\mathrm{S}$ trend of the mineralised layers of the central orebody (Fig.4). 
Such field situation is explained in terms of the structural evolution of the orebody itself, which has been interpreted as a pre- or syn- $\mathrm{D}_{1}$ sheet-like intrusive body (Fig. 11A), whereby the mineralised layers acquired the $S_{1}$ metamorphic banding probably by shearing parallel to the igneous layering. Actually, a system formed by a frontal and a lateral ramps that were climbed by the mineralised layers during the evolution of the E-W trending $\mathrm{F}_{2}$ folds (Fig. $1 \mathrm{IB}$ ) provides the structural elements for generation of the different trends of the rocks after $\mathrm{F}_{3}$ folding (Fig. 11C), as seen in the surface map of the Mine.

It is interesting to note that if Caraíba is a $\mathrm{F}_{2} \mathrm{XF}_{3}$ mushroom, the existence of a E-W trending frontal ramp fits well with the suitable place for development of the $\mathrm{F}_{2}$ folds and duplication of the original sill. The N-S trending lateral ramp is also well supported by the geology of the Mine, as the calcsilicate rocks that lie at the northeastern contact of the orebody may well have acted as lubricant layers during deformation, thereby capable of accommodating any differential movement during $\mathrm{D}_{2}$ thrusting and folding by developing a N-S trending shear zone (lateral ramp) that would be reworked during $\mathrm{D}_{3}$.

Is Caraíba a swarm of pos-tectonic or syn-F3 intrusions? To study the Mine in the detail of a PhD thesis, Oliveira (1990) logged three bore holes and sampled two of them for mineral and chemical analyses, as well as four outcrops in the open pit of Caraíba. He interpreted the whole orebody as made up of multiple veins or dyke-like intrusions (and breccias) of hypersthenites, norites, and anorthosites, with peridotite and gabbro xenoliths (see also Oliveira \& Tarney 1993). The sub-vertical dyke-swarm would have been emplaced around $1.89 \mathrm{Ga}$ (whole rock $\mathrm{Sm}-\mathrm{Nd}$ isochron of hypersthenite) after the main period of crustal growth. Oliveira \& Lacerda (1993) described four dm- to m-scale outcrops in Caraíba and interpreted them in terms of syn- $\mathrm{F}_{3}$ intrusions of thin layers of pyroxenites during a dextral shearing on a vertical plane, that is, the bench walls (see also Fig.5 in Oliveira \& Tarney 1995). Since then the orebody has been interpreted as a swarm of syn- $\mathrm{F}_{3}$ multiple intrusions. More recently, Oliveira \& Lafon (1995) interpreted a $2001+/-35$ $\mathrm{Ma} \mathrm{Pb}-\mathrm{Pb}$ zircon evaporation age as crystallisation age of hypersthenites, and re-interpreted the $1.89 \mathrm{Ga} \mathrm{Sm}-\mathrm{Nd}$ isochron of Oliveira (1990) as the age of a regional episode of late shearing and metasomatic recrystallisation of biotite.

It is out of the scope of this paper to discuss the data produced by Oliveira and co-authors, despite their structural interpretations being highly problematic. As a single example, the $\mathrm{F}_{3}$ event is associated with a sinistrai transpressive regime in Caraíba (Rocha 1987) and also about $300 \mathrm{~km}$ to the south (D'el-Rey Silva 1993, D'el-Rey Silva et al 1994) - not with a dextral shearing on a vertical plane. As the banding is folded, the small-scale structures drawn in Oliveira \& Lacerda (1993) may wellbesyn- $\mathrm{F}_{1}$.

Instead, time and space are saved by immediately assuming that Oliveira and co-authors are correct. To do this, we should forget for a while the thousand of structural and geology data points collected in several hundreds of outcrops, outside and within the Mine (open pit and underground sites), during several years of detailed geological mapping; the twice folded orebody-gneiss migmatised contact and the internal banding in the mineralised layers; the $\mathrm{S}_{1}$ foliation data in hundreds of bore holes; the carefully checked cross-sections of the Mine; the similar map geometry of the orebody in the four first benches of the open pit and in the sub-levels of the underground mine; the map pattern produced by thousands of Cu-grade values from drill holes for blasting in the Mine, and so on. Then we may try to put Oliveira and his co-authors' data and interpretations in the geology of the Curaçá Valley and the Caraíba Mine itself:
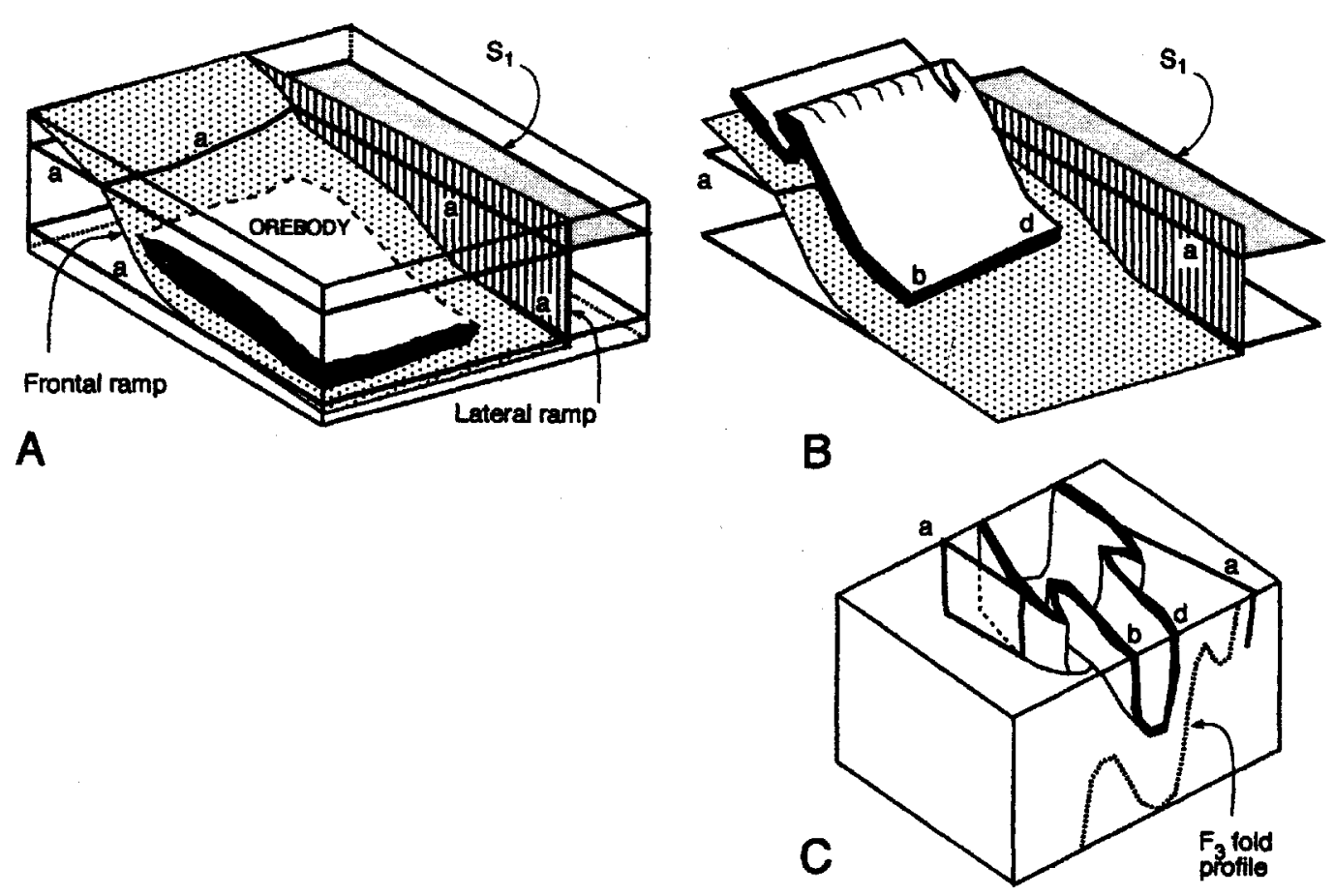

Figure 11 - Cartoons not to scale to illustrate a possible model of formation of the FI folds in the Caraiba orebody associated with an E-W trending frontal ramp and a N-S trending lateral ramp. The orebody is interpreted as a sub-horizontal sill, emplaced sub-parallel to $S_{1}$ in the country rocks $(\boldsymbol{A})$. Layers labelled a are also shown in $(\boldsymbol{E})$, where the orebody has already climbed the ramp system, and dips moderately to the south, then making an angle with the sub-horizontal layers. Layers labelled a, and points $\mathbf{b}, \mathbf{d}$ are also in $(\boldsymbol{C})$ : after $\mathrm{Fa}$ the western and eastern borders of the Caraiba mushroom trend differently from layers labelled $\mathbf{a}$. The profile of the limb of the Caraiba antiform is also indicated. See text for details. 
1 - To intrude Oliveira's dykes syn-tectonicaly with FS requires the opening of a space within a sinistrai, N-S trending transcurrent system (the sense of movement is not relevant here). In such a tectonic situation, intrusions may occupy voids created by releasing bends or along openings parallel to several vertical planes that are theoretically predictable (Fig. 12), and some of these sheet-like voids could be theoretically folded straightforward or first rotated and then folded, but these FS folds would have vertical axes unlike the Caraíba orebody, where they are gently double plunging. Therefore, the Caraíba orebody was not emplaced syn- $\mathrm{F}_{3}$.

2 - The $2051+/-16 \mathrm{Ma}$ old $\mathrm{G}_{3}$ granites cross-cut the hinge zone of proven $100 \mathrm{~m}$-scale Fa folds that affect the mineralised layers in Caraíba, and which also intruded the hypersthenites in Surubim and Vermelhos, far to the north in the Curaçá Valley. Therefore, the hypersthenites/norites were emplaced before both the $\mathrm{F}_{3}$ folds and the $\mathrm{G}_{3}$ granites. Thus the $\mathrm{Pb}$ evaporation age of Oliveira \& Lafon (1995) must be taken as a minimum age, as it does not fit the time of emplacement of the mineralised layers.

3 - Even assuming that Oliveira's syn- $\mathrm{F}_{3} \mathrm{Cu}$-rich dykes could have been emplaced and folded as above, why are the $\mathrm{G}_{3}$ granites (which are actually syn- $\mathrm{F}_{3}$ intrusions, always sub-vertical, sheet-like and N-S trending everywhere in the Curaçá Valley) never folded? Why should there be one mode of emplacement for the hypersthenites and another for the $\mathrm{G}_{3}$ granites, if they are both contemporaneous with $\mathrm{F}_{3}$ ? Why is there not, in all the space of the Curacá Valley terrane, a single E-W trending, sub-vertical, unfolded layer of hypersthenite or $\mathrm{G}_{3}$ granite?

We acknowledge the contribution of some findings of Oliveira and co-authors, particularly about polyintrusions, some original brecciation, and the $1,89 \mathrm{Ma}$ age for the late- $\mathrm{D}_{3}$ shearing. However, it seems impossible to fit the other data in the evolution of Caraíba and surroundings. Thus, the inevitable conclusion is that there is not a problem of conflicting interpretation on the genesis of the Caraíba orebody, as suggested in Oliveira \& Lafon (1995). In reality there is an incompatibility between two sets of data, and this has resulted in conflicting interpretations. One set of data has been obtained by several authors working independently throughout the last 18 years, and their interpretations have been checked against the fload of data produced by the exploitation of the Mine up to the end of 1996. The other set derives from a group led by one author, in the last six years, based on local observations, and does not fit the local and regional geology.

The incompatibility of data persists concerning the metamorphic evolution of the orebody, as well. Concerning the Mine, Oliveira stated that (his page 16 1990): "The banded gneiss,..., consists mainly of granulite facies tonalitic bands interleaved with dark bands of gabbro-noritic to enderbitic composition. In many places it does not differ significantly from $\mathrm{G}_{2}$ and $\mathrm{G}_{3}$ orthogneisses. The ore bearing mafic-ultramafic rocks do not exhibit significant changes by metamorphic fluids, as observed in the country rocks." Nevertheless, Lacerda \& Oliveira (1995) introduced that the orebody underwent amphibolite facies metamorphism assisted by abundant fluids, and denied the granulite facies metamorphism defended since Townend et al. (1980) who logged tens of kilometres of drill cores in Caraíba and in the Curaçá Valley terrane.

Independent, more recent and systematic petrological, petrographic and chemical studies carried out in Caraíba (and in the Curaçá Valley) have concluded that the sill-like orebodies in fact underwent granulite facies metamorphism, as indicated by a change in the composition of the oxides in the ore, due to equilibration with orthopyroxene displaying a typical metamorphic texture (Mayer \& Barnes 1996).

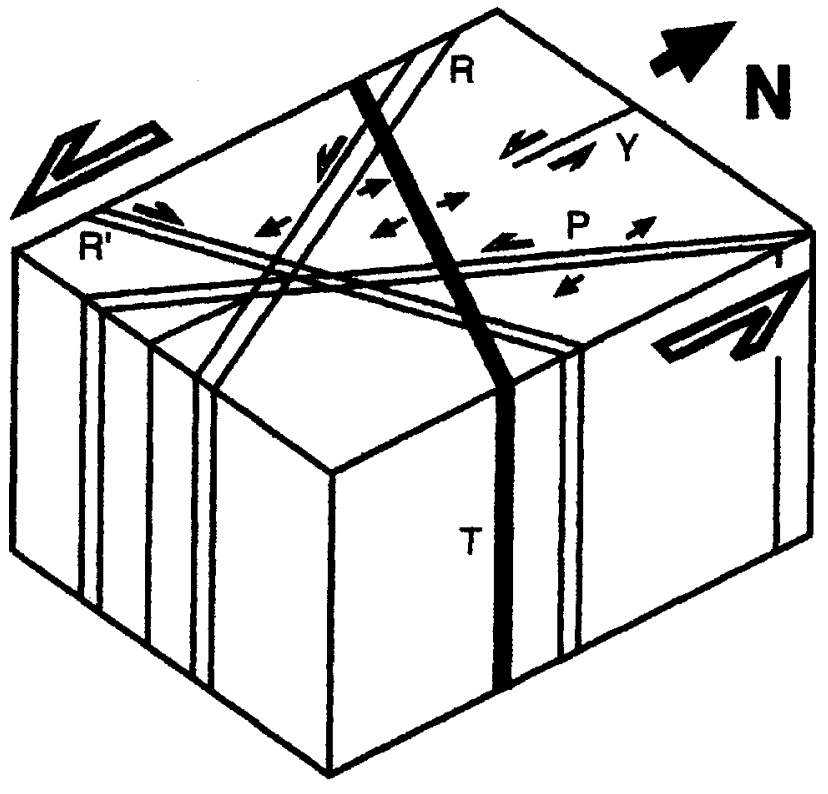

Figure 12 - Cartoon not to scale to indicate the main sub-vertical planes associated with a N-S trending sinistrai shear. Voids opened parallel to such planes would be theoretically the preferred site for emplacement of syn- $F_{3}$ bodies of any rock type. The extensional fracture $T$ and the anti-Riedel's shear fracture $R^{\prime}$ make high angle with the north direction. See text for details.

CONCLUSIONS The Caraíba Mine is a sill-like, $\mathrm{Cu}$ bearing hypersthenite-norite orebody polydeformed-metamorphosed in response to the U-Pb 2.25-2.05 Ga old orogenesis whereby three deformational events affected the Curaçá Valley area, generally assisted by voluminous melts and/or tonalitic-granodioritic-granite syn-tectonic intrusions. The first event was N-S trending and developed a penetrative, amphibolite facies, sub-horizontal migmatitic metamorphic banding associated with intrafolial folds. The second event was nearly E-W trending and developed sub-recumbent folds, and a gently-moderately dipping foliation associated with granulite facies metamorphism. The third event developed $\mathrm{N}-\mathrm{S}$ trending, upright to steeply inclined folds verging mostly to the east and plunging gently to both $\mathrm{N}$ and $\mathrm{S}$. $\mathrm{D}_{3}$ was so intense and ductile that it brought most of the earlier structures into parallelism with the penetrative $S_{3}$ foliation, whereas intense migmatisation and $\mathrm{G}_{3}$ granite intrusion have hampered the reconstruction of the structural evolution of the whole area. Late shearing and shear zone-controlled greenschist retrometamorphism, kinematically and thermally compatible with the structural evolution of the Mine took place up to $1.89 \mathrm{Ga}$ (Sm-Nd isochron age on hypersthenites).

Nevertheless, because of the structures, the structural-metmorphic evolution, and the geometry of the orebody, the Caraíba sill must have been emplaced pre- or early-syn $\mathrm{D}_{1}$ in the area. As a result, the Caraíba Cu-deposit is controlled by a N-S trending, tight-isoclinal and asymmetric $\mathrm{F}_{3}$ synform, with $\approx 1000 \mathrm{~m}$ of amplitude and axial plane dipping $70^{\circ}-75^{\circ}$ to the $\mathrm{W}$. This synform lies on the western limb of a normal, regional-scale FS antiform plunging about $18^{\circ}$ to the $\mathrm{S}$. Due to $\mathrm{F}_{2} \mathrm{XF}_{3}$ interference, the orebody acquired a N-S trending, nearly 5 $\mathrm{km}$-long and $800 \mathrm{~m}$-wide mushroom-shaped geometry. Actually, the orebody was possibly built by episodic intrusion and, because the mineralised layers were relatively resistant throughout the $\mathrm{D}_{1}-\mathrm{D}_{3}$ deformation, some original true breccia 
structures may have remained preserved whereas other breccia-like features were produced by solid-state deformation.

Much research on regional geology, structural evolution, petrology, and geochemistry, together with a huge amount of data from 18 years of mining operation, has placed Caraíba on the level of a very well-known Cu-orebody. Missing studies include a detailed petrological-chemical analysis of the orebody layers, in order to define any original igneous facing not clearly established, yet.
Acknowledgements -We thank Mineração Caraíba LIDA for permission to publish the new data in this paper, and Dr. Tim Liverton (UnB-IG) for reading and criticism of the first draft. We acknowledge Dr. O. Kouvo (Geological Survey of Finland) for determination of the U-Pb age presented here. D'el-Rey Silva thanks CNPq for Grant 520241/95-9.

\section{REFERENCES}

BARBOSA, J.S.F. 1996. O embasamento Arqueano e Proterozóico Inferior de Estado da Bahia. In Geologia da Bahia, Texto Explicativo (edited by J.S.F. Barbosa \& J.M.L. Dominguez), SME-SGM, Capítulo III: 63-83.

BARBOSA, J.S.F., SABATÉ, P. \& DOMINGUEZ, J.M.L. 1996. O estado da Bahia na Plataforma Sul-Americana, suas sub-divisões, critérios de empilhamento estratigráfico das coberturas plataformais e ciclos geotectônicos. In Geologia da Bahia, Texto Explicativo (edited by J.S.F. Barbosa \& J.M.L. Dominguez), SME-SGM, Capítulo II: 41-61.

BELLO, R.M.S. 1986. Jazida de Cobre de Surubim, Vale do Curacá, Bahia: Mineralogia, Petrografia e Petrogenese. Unpublished $\mathrm{PhD}$ Thesis, USP, São Paulo, 280p.

BRITO NEVES, B.B. de, CORDANI, U.G. \& TORQUATO, J.R.F. 1980 Evolução geocronológica do precambriano do Estado da Bahia Geologia e Recursos Minerais do Estado da Bahia, SME, Série Textos Básicos 3: 1-80.

CONCEIÇÃO, H. 1990. Petrologie du massif syénitique d'ltiuba: contribution à l'étude minéralogique des raches alcalines dans 1'État de Bahia (Brésil). Unpublished PhD Thesis, University of Paris-Sul, Orsay, France, 393p.

D'EL-REY SILVA, L.J.H. 1984. Geologia e controle estrutural do depósito cuprífero Caraíba, Vale do Curacá, Bahia, Brasil. Unpublished MSc Thesis, UFBa, Salvador 158p.

D'EL-REY SILVA, L.J.H. 1985. Geologia e controle estrutural do depósito cuprífero Caraíba, Vale do Curacá, Bahia. Geologia e Recursos Naturais do Estado da Bahia, SME, Série Textos Básicos 6: 51-123.

D'EL-REY SILVA, L.J.H. 1992. A mina de Caraíba (Ba): controle estrutural e implicações no planejamento da lavra. In Geologia Estrutural Aplicada (edited by Hasui, Y. \& Mioto, J. A.) ABGE-Votorantim, 327-348.

D'EL-REY SILVA, L.J.H. 1993. Geologia Estrutural e Tectônica na área do Projeto Lajedinho-Ipirá. Consulting report for CBPM, Salvador, 23p., 23 figures.

D'EL-REY SILVA, L.J.H., CAVALCANTE, P.R.B., MOTA, E.R. \& ROCHA, A.M.R. da 1988. Controle estrutural da mina de cobre Caraíba: implicações na lavra e na tectônica das faixas móveis do Proterozóico Inferior. XXXV Congresso Brasileiro de Geologia, Belém, Anais SBG 1: 16-29.

D'EL-REY SILVA, L.J.H., OLIVEIRA, J.G. \& LIMA E SILVA, F.J. 1994. The Mushroom-shaped Caraíba Cu-deposit, Vale do Curaçá-Ba: Understanding the Structural Evolution of the Paleoproterozoic, Granulitic Ipirá-Curaçá Belt within the São Francisco Craton. XXXVIII Congresso Brasileiro de Geologia, Camboriú, SBG, Boletim de Resumos Expandidos 2: 175-177.

FERREIRA, P.F.M. and 6 co-authors 1978. Relatório Final Projeto Especial Caraíba. Unpublished DOCEGEO-CVRD Report, 6 volumes.

FIGUEIREDO, M.C.H. 1976. Geologia e geoquímica da região de Poço de Fora - Vale do Rio Curacá - Bahia. Unpublished MSc Thesis, UFBa, Salvador, $87 \mathrm{p}$.

FIGUEIREDO, M.C.H. 1980. Geochemistry of high-grade metamorphic rocks, northeastern Bahia. Unpublished PhD Thesis, Western Ontario University, Canada, 220p.

FIGUEIREDO, M.C.H. 1981. Geoquímica da rochas metamórficas de alto grau do nordeste da Bahia-Brazil. Geologia e Recursos Naturais do Estado da Bahia, SME, Série Textos Básicos 4: 1-71.

GAÁL, E.G. 1982a. Evaluation of Geological, Geophysical and Geochemical data of the Curacá Valley and the Mundo Novo -Uauá - Rio Capim Area. Internal Report for the Mineração Caraíba, MID-066/82.

GAÁL, E.G. 1982b. Evaluation of exploration methods applied in the Curaçá Valley and recommendations for future prospecting of copper and nickel-copper deposits akin of the Caraíba Copper Deposit. Internal Report for the Mineração Caraiba, MID-045/82.
HASUI, Y., D'EL-REY SILVA, L.J.H., LIMA e SILVA, F.J., MANDETTA, P., MORAES, J.A.C. de, OLIVEIRA, J.G. \& MIOLA, W. 1982. Geology and copper mineralization of Curaçá River Valley, Bahia. Revista Brasileira de Geociências 12(1-3): 463-474.

INDA, H.A.V. e BARBOSA, J.S.F. 1978. Mapa geológico do Estado da Bahia, escala 1:1.000.000. Texto explicativo. SME/CPM.

JARDIM de SÁ, E.F., ARCANJO, C.J. \& LEGRAND, J-M. 1982. Structural and metamorphic history of part of the high-grade terrane in the Curacá Valley, Bahia, Brazil. Revista Brasileira de Geociências 12: 251-262.

LACERDA, C.M.N. \& OLIVEIRA, E.P. 1995. Relações Paragenéticas do Complexo Cuprífero de Caraíba, Bahia. V Congresso Brasileiro de Geoquímica e III Congresso de Geoquímica de Países de Língua Portuguesa, Niterói, Anais (Iso 15).

LINDENMAYER, Z.G. 1981. Evolução geológica do Vale do Curaçá e dos corpos máfico-ultramáficos mineralizados a cobre. Unpublished MSc Thesis, UFBa, Salvador 140p.

LINDENMAYER, Z.G. and 6 co-authors 1984. Projeto Cu Bahia, Relatório Final. Unpublished DOCEGEO-CVRD Report 3 volumes.

MANDETTA, P. 1982 - Aspectos geológicos e petrogenéticos das associações máfico-ultramáficas da região de Caraíba, Vale do Curacá / Ba. Unpublished MSc Thesis, UFBa, Salvador.

MASCARENHAS, J. de F., PEDREIRA, A.J., MISI, A., MOTA, A.C. \& SÁ, J.H. da S. 1984. Província São Francisco. In O Precambriano do Brasil (edited by F.F.M. Almeida e Y. Hasuy) Edgard Blucher Editora, São Paulo: 46-122.

MAYER, W.D. \& BARNES, S-J. 1996. Unusually high concentrations of magnetite at Caraíba and other Cu-sulphide deposits in the Curaçá Valley, Bahia, Brazil. The Canadian Mineralogist 34:717-731.

OLIVEIRA, E.P. 1990. Petrogenesis of Maflc-Ultramafic Rocks from the Precambrian Curaçá Terrane, Brazil. Unpublished PhD Thesis, University of Leicester, UK, $287 \mathrm{p}$.

OLIVEIRA, E.P. \& LACERDA, C.M.N. 1993. Field evidence for the synkinematic emplacement of the Caraíba Hypersthenites, Bahia- Brazil. II Simpósio do Cráton do São Francisco, Salvador, SBG Anais, 89-92.

OLIVEIRA, E.P. \& TARNEY, J. 1993. Genesis of the Copper-Rich Caraíba Norite-Hypersthenite Complex, Brazil. IAGOD -International Symposium on Mineralization Related to Mafic and Ultramafic Rocks, Orleans, France, Terra Abstracts, Suplement 3 (5), 39-40.

OLIVEIRA E.P. \& TARNEY, J. 1995. Genesis of the Precambrian copper-rich Caraíba hypersthenite-norite complex, Brazil. Mineralium Deposita 30: 351-373.

OLIVEIRA, E.P. \& LAFON, J-M. 1995. Idade dos Complexos Máfico-Ultramáficos Mineralizados de Caraíba e Medrado, Bahia, por Evaporação de $\mathrm{Pb}$ em Zircão. V Congresso Brasileiro de Geoquímica e III Congresso de Geoquímica de Países de Língua Portuguesa, Niterói,-RJ, Anais (ISO 15).

RAMSAY, J.G. 1967. Folding and Fracturing of Rocks. McGraw Hill, 568p.

ROCHA, W. de J. S. da F. 1987 - Controles da mineralização de cobre do depósito Caraíba. I Simpósio Nacional de Estudos Tectônicos, Salvador, Boletim de Resumos, 77-79.

SABATÉ. P., MARINHO, M.M., Vidal, P. \& CAEN-VACHETTE, M. 1990. The 2-Ga peraluminous magmatism of the Jacobina-Contendas Mirante belts (Bahia, Brazil): Geological and isotopic constraints on the sources. Chemical Geology 83: 325-338.

SILVA, M. da G. da 1996. Seqüências metassedimentares, vulcanosedimentares e greenstone belts do Arqueano e Proterozóico Inferior. In Geologia da Bahia, Texto Explicativo (edited by J.S.F. Barbosa \& J.M.L. Dominguez), SME-SGM, Capítulo IV: 86-102.

TOWNEND, R., FERREIRA, P.M. \& FRANKE, N.D. 1980. Caraíba, a new copper deposit in Brazil. The Institution of Mining and Metallurgy 89: B159-B164.

MANUSCRITO A909 Recebido em 24 de fevereiro de 1997 Revisão dos autores em 20 de abril de 1997 Revisão aceita e 